\title{
The use of long non-coding RNAs as prognostic biomarkers and therapeutic targets in prostate cancer
}

\author{
Cristian Arriaga-Canon ${ }^{1}$, Inti Alberto De La Rosa-Velázquez², Rodrigo González- \\ Barrios $^{3}$, Rogelio Montiel-Manríquez ${ }^{3}$, Diego Oliva-Rico ${ }^{3}$, Francisco Jiménez- \\ Trejo $^{4}$, Carlo Cortés-González ${ }^{3}$ and Luis A. Herrera ${ }^{3}$ \\ ${ }^{1}$ CONACYT- Instituto Nacional de Cancerología, Tlalpan. C.P. 14080, CDMX, Mexico \\ ${ }^{2}$ Universidad Nacional Autónoma de México, Laboratorio de Genómica, CIC-Red de Apoyo a la Investigación, INCMNSZ, \\ Colonia Belisario Domínguez Sección XVI, Delegación Tlalpan C.P.14080, CDMX, Mexico \\ ${ }^{3}$ Unidad de Investigación Biomédica en Cáncer, Instituto Nacional de Cancerología-Instituto de Investigaciones Biomédicas, \\ Tlalpan. C.P. 14080, CDMX, Mexico \\ ${ }^{4}$ Instituto Nacional de Pediatría, Coyoacán. C.P. 04530, CDMX, Mexico \\ Correspondence to: Luis A. Herrera, email: metil@hotmail.com \\ Keywords: long non-coding RNAs; prostate cancer; prognosis; precision medicine; therapeutic targets
}

Received: July 04, $2017 \quad$ Accepted: March 15, $2018 \quad$ Published: April 17, 2018

Copyright: Arriaga-Canon et al. This is an open-access article distributed under the terms of the Creative Commons Attribution License 3.0 (CC BY 3.0), which permits unrestricted use, distribution, and reproduction in any medium, provided the original author and source are credited.

\section{ABSTRACT}

Prostate cancer is the most common cancer in men and the second leading cause of cancer-related deaths. The most used biomarker to detect prostate cancer is Prostate Specific Antigen (PSA), whose levels are measured in serum. However, it has been recently established that molecular markers of cancer should not be based solely on genes and proteins but should also reflect other genomic traits; long non-coding RNAs (IncRNAs) serve this purpose. IncRNAs are transcripts of $>\mathbf{2 0 0}$ bases that do not encode proteins and that have been shown to display abnormal expression profiles in different types of cancer. Experimental studies have highlighted IncRNAs as potential biomarkers for prognoses and treatments in patients with different types of cancer, including prostate cancer, where the PCA3 IncRNA is currently used as a diagnostic tool and management strategy. With the development of genomic technologies, particularly next-generation sequencing (NGS), several other IncRNAs have been linked to prostate cancer and are currently under validation for their medical use. In this review, we will discuss different strategies for the discovery of novel IncRNAs that can be evaluated as prognostic biomarkers, the clinical impact of these IncRNAs and how IncRNAs can be used as potential therapeutic targets.

\section{INTRODUCTION}

Prostate cancer $(\mathrm{PCa})$ is the most common cancer in American men and the second leading cause of cancer deaths in Americans, behind lung cancer. The American Cancer Society has estimated 180,890 new cases of $\mathrm{PCa}$ in the United States for 2016 and approximately 26,120 deaths. This shows that approximately 1 man in 7 will be diagnosed with PCa during his lifetime [1]. Because these numbers are similar throughout different regions of the world, $\mathrm{PCa}$ is expected to be one of the most serious medical challenges in the coming years [2]. PSA levels and digital rectal examination (DRE) are the main methods for early detection of $\mathrm{PCa}$, and the prostate biopsy is considered the gold standard in patients with suspected PCa after DRE or when PSA levels are increased [3]. Currently, there are discrepancies regarding the effectiveness of PSA testing, given that different clinical trials have shown that PSA is inconsistent in its effectiveness for detecting $\mathrm{PCa}$ and reducing overall 
deaths [4]. Thus, the search for new biomarkers has become highly necessary. In this context, several studies have aimed to identify different molecular markers in PCa, but most of them have focused primarily on genes and proteins $[5,6]$. PTEN and TMPRSS2-ERG are molecular markers based on genes that have been used to determine prognostic parameters such as biochemical recurrence (BCR) and progression-free survival (PFS) but their clinical utility as molecular prognostic tools is still unclear [7]. However, other genomic and epigenetic traits can also be useful as potential biomarkers for cancer, particularly the long non-coding RNAs (lncRNAs). The expression levels of numerous lncRNAs are altered in several types of cancer, and several lncRNAs are already used as molecular tools for diagnosis and prognosis of cancer like H19, HULC and HOTAIR [8-10].

Conceptually, lncRNAs are defined as transcripts that are longer than 200 bases that do not have coding potential, which means that lncRNAs do not give rise to a functional protein. The lncRNAs usually contain a CAP at the $5^{\prime}$ end, although this biochemical modification is not always present. Likewise, IncRNAs can be polyadenylated and spliced into several isoforms. This suggests that there may be a high diversity of IncRNAs in the human genome [11]. Depending on their genomic location and the sense in which they are expressed, IncRNAs can be divided into intergenic, intragenic, bidirectional, enhancers, as well as sense and antisense lncRNAs, however much debate remains on how to classify this type of non coding transcripts $[12,13]$. The use of new technology, specifically next-generation sequencing of RNA (RNASeq), has enabled several groups to demonstrate that the number of lncRNAs in the human genome is higher than the number of genes that encode proteins and that the lncRNA expression pattern is more specific than many of the known genes [14]. In terms of compartmentalization, lncRNAs are localized in the nucleus and the cytoplasm and one of the main features of lncRNAs is that they are synthesized at low rates, resulting in IncRNA abundance being orders of magnitude lower than that of messenger RNAs, and this particular feature makes lncRNA detection elusive to less sensitive methods $[15,16]$.

Regarding lncRNA-specific functions, these RNAs may be involved in different biological processes, including chromatin structure regulation [17], DNA methylation [18], genomic imprinting [19], translation regulation [20] and nuclear sub-compartment formation [21], among other functions [22]. This reveals the importance of this type of non-coding transcript in the regulation of different biological processes.

As mentioned previously, one of the particularities about lncRNAs is that they have abnormal expression profiles in different types of cancer, and there is evidence that the development and pathogenesis of cancer is directly associated with lncRNAs [23-25]. Actually, lncRNAs have already been approved by the Food and
Drug Administration (FDA) as biomarkers that improve clinical management of patients showing the great importance of these non-coding transcripts in the clinic [26]. One of the advantages of lncRNAs for clinical use is their high stability in human fluids, which facilitates IncRNA detection in blood [8], urine [27], and saliva [28] which allow their detection with minimum invasion to the patient.

Some lncRNAs, including HOTAIR [29], ANRIL [30], MALAT1 [31], and GAS5 [32], have been included in the general list of molecular biomarkers for cancer, and the number of lncRNAs has increased in the last few years, highlighting the importance of investigations into the use of lncRNAs as molecular markers in different types of cancer. Several lncRNAs have been studied and characterized in $\mathrm{PCa}$ [33]. Nevertheless, only a few lncRNAs have been characterized as biomarkers for $\mathrm{PCa}$ prognosis [34]. In the following section, we will provide a detailed description of each lncRNA.

\section{LncRNAs AS PROGNOSTIC BIOMARKERS IN PROSTATE CANCER}

\section{PCA3}

PCA3 (Prostate Cancer gene 3), also known as DD3, was reported in 1999 by Bussemakers and colleagues and is one of the first lncRNAs to be discovered in PCa [35]. PCA3 is located in chromosome $9 \mathrm{q} 21-22$, it is a $2-4-\mathrm{kb}$ polyadenilated transcript with different isoforms, and its expression is prostate specific. Sequence analyses of PCA3 have shown that this transcript does not have a coding potential and have been found overexpressed in $95 \%$ of prostate neoplastic tissue compared to normal tissue $[35,36]$. It has been shown that PCA3 play essential roles in diverse cellular processes and biological functions. It is involved in the control of cell survival in PCa, partly through modulation of Androgen Receptor (AR) signaling, including the regulation of androgen-regulated genes (TMPRSS2, PSA, and FGF8) [37], It is also involved in the regulation of genes involved in processes like angiogenesis (IFNB1, COL18A1 and VEGFA), cell adhesion (MTSS1 and ITGB1), signal transduction (MAP2K1, ERBB2 and PIK3R1), apoptosis and cell senescence (TERT, BAD, and TNFRSF25), invasion and metastasis (MTA2 and PLAUR), and DNA damage repair (BRCA1). PCA3 also controls PRUNE2 levels through a regulatory mechanism that involves RNA editing (the adenosine deaminases acting on RNA (ADARs)) thus, the foregoing examples demonstrate the great importance of this non-coding transcript in PCa pathogenesis [38, 39]. Based on the importance of PCA3 in PCa, PROGENSA, a commercial test, was developed and approved by the FDA in 2012. This test is used to quantify the expression of PCA3 in urine samples from DRE positive patients and to normalize it to PSA expression levels, after which a 
"PCA3 score" is obtained to determine the need for repeat prostate biopsies in men who have had a previous negative biopsy [26]. However, its potential as a prognostic biomarker is still under development [40-42]. A study with a cohort of 207 patients showed that high PCA3 scores (approximately 35) were associated with high Gleason scores, a high percentage of positive cores and advanced clinical stage, which suggests that PCA3 is a biomarker of a poor prognosis [43]. Although efforts have been made to propose PCA3 as a prognostic marker, clinical evidence is still at an early stage to consider this transcript as a true prognosis biomarker for PCa. In spite of it, the PCA3 test has been useful in clinical trials to reducing the number of biopsies [44] and is a clear example of the importance of lncRNAs as potentially useful molecular markers in $\mathrm{PCa}$ but further efforts are needed to include this non-coding transcript as a prognostic biomarker in $\mathrm{PCa}$.

\section{PCAT1}

The Prostate Cancer associated lncRNA Transcript 1 (PCAT-1) is a $\sim 2 \mathrm{~kb}$ lncRNA that is polyadenylated, localized to chromosome $8 \mathrm{q} 24$ and expressed in neoplastic and metastatic prostate tissues, among other cancers [45-47]. In vitro experiments and sequence analysis confirm that PCAT-1 is not translated [47]. Moreover, experimental evidence has shown that PCAT1 negatively regulates $B R C A 2$ in $\mathrm{PCa}$. Repression of $B R C A 2$ expression results in a functional deficiency in homologous recombination, which increases sensitivity to radiotherapy and inhibitors of PARP1 [48]. Furthermore, an independent study showed that PCAT1 promotes prostate cell proliferation via upregulation of the gene $c M y c$ [49]. These studies suggest that PCAT-1 is involved in deregulating DNA repair pathways through BRCA2 silencing and in deregulating cell proliferation through $c M y c$ in PCa. Other studies conducted in esophageal squamous carcinoma, colorectal cancer and hepatocellular cancer have highlighted the strong potential of PCAT1 as a biomarker of poor prognosis, linking its overexpression to cancer tissue invasion, lymph node metastasis, advanced tumor stage and low survival [50-52]. Therefore, PCAT1 may represent a molecular marker that is highly valuable for prognoses and predictions in response to the therapies used in PCa. However, additional studies are needed to develop PCAT1 detection via non-invasive methods (urine or blood) and determine whether PCAT-1 detection is a useful prognostic biomarker in $\mathrm{PCa}$.

\section{SChLAP1}

The SChLAP1 transcript (second chromosome locus associated with prostate-1), also known as LINC00913, is an intergenic long non-coding RNA (lincRNA), with a length of approximately $1.4 \mathrm{~kb}$. SChLAP1 is localized to chromosome $2 \mathrm{q} 31.3$, is polyadenylated, and has different isoforms. In vitro and sequence analyses have confirmed that SChLAP1 is a non-coding transcript. SChLAP1 is overexpressed in $25 \%$ of $\mathrm{PCa}$ and is associated with metastasis [53]. Expression of SChLAP1 is an independent predictor of aggressive PCa when the routine clinicopathological factors of this neoplasia are considered. Another important feature of this lincRNA is the association of its high expression level with biochemical recurrence (BCR), metastasis progression and mortality [54]. An independent study demonstrated that SChLAP1 has a high prognostic value with high specificity values that have been confirmed by in situ hybridization [55]. Given the importance of SChLAP1 as a biomarker in $\mathrm{PCa}$, the development of several tests based on RNA in situ hybridization has commenced to link high SChLAP1 expression levels to the results of radical prostatectomy in patients with clinically localized disease [56]. This type of test will be helpful toward establishing whether the patient will have a good prognosis after a radical prostatectomy. Furthermore, quantification of SChLAP1 by PCR in urine samples [54] has shown SChLAP1 to be a biomarker that can be used to identify PCa patients at higher risk of lethal progression [57], which establishes this lncRNA as a molecular biomarker with a strong potential for use in the clinic as a prognostic tool for PCa.

\section{PCGEM1}

Prostate Specific Transcript 1, or PCGEM1, is another IncRNA that exhibits tissue-specific expression in the prostate. This lncRNA is localized to the $2 \mathrm{q} 32$ chromosome, and its length is approximately $1.6 \mathrm{~kb}$. PCGEM1 was identified through a differential display analysis of paired normal and PCa tissues [58]. The experimental data showed high expression of this lncRNA in high risk groups, particularly Afro-American men, who are known to be more susceptible to PCa than Caucasian or American men [59]. Detailed studies have established that PCGEM1 is regulated by androgenic receptors and can interact them such that PCGEM1 can consequently potentiate the activation of genes regulated by AR $[60,61]$. Although PCGEM1 has been associated with $\mathrm{PCa}$, there is evidence that suggests that this lncRNA cannot be considered as a prognostic marker for PCa [62]. Thus, clinical studies are needed to support the role of PCGEM1 as a biomarker in PCa.

\section{IncRNA-ATB}

lncRNA-ATB (long non-coding RNA activated by TGF- $\beta$ ) is approximately $2.4 \mathrm{~kb}$ long, is located on chromosome $14 \mathrm{q} 11.2$ and is not polyadenylated. It was first discovered as an RNA that is associated with the epithelial-mesenchymal transition (EMT) through the of ERK and P13k/AKT signaling pathways [63] and as a prognostics biomarker for hepatocellular carcinoma [64]. 
A study conducted by $\mathrm{Xu}$ and colleagues using a cohort of 57 patients who underwent radical prostatectomy showed that lncRNA-ATB is expressed at high levels in neoplastic tissue compared to normal adjacent tissue [63]. A more detailed analysis showed that IncRNA-ATB expression can be an independent prognostic factor for biochemical recurrence free survival (BCR-FS) in PCa patients [63]. Thus, studies establish that overexpression of lncRNA-ATB is associated with aggressive clinicopathological parameters, such as high histological grade, high preoperative PSA level, high Gleason score, lymph node metastasis and has been suggested like an independent prognostic factor for BCR-FS in PCa patients [63]. Several studies have suggested the role of lncRNAATB as a prognostic biomarker in different types of cancer [65-67]. However, clinical trials or multicenter studies are needed to establish whether this transcript can be used clinically as a true prognostic biomarker in $\mathrm{PCa}$.

\section{LOC400891}

LOC400891 is another IncRNA that is associated with $\mathrm{PCa}$ prognosis. This transcript is located on chromosome 22q11.2, and its length is approximately $2.5 \mathrm{~kb}$ according to the public database for ncRNAs NRED [68]. In a cohort of 81 patients with $\mathrm{PCa}$ who underwent radical prostatectomy and laparoscopy, lncRNA LOC400891 was shown to be overexpressed in neoplastic tissues compared to normal adjacent tissue using expression microarrays. The Kaplan-Meier survival curve analysis showed that patients with high LOC400891 expression had poor prognoses compared to patients with normal LOC400891 expression. Likewise, a multivariate analysis also showed that LOC400891 expression was an independent prognostic factor for BCR-FS in prostate cancer patients [69]. Additionally, studies to evaluate the effects of LOC400891 showed that high expression of LOC400891 promotes growth and metastasis by inducing the PI3K/Akt/mTOR signaling pathway, the PTEN gene and the EMT process [69].

However, the data suggesting that LOC400891 may be a promising candidate as molecular marker for prognostics in $\mathrm{PCa}$ and as a therapeutic target for $\mathrm{PCa}$ treatment comes only from one study, so, more molecular studies are needed to to establish whether this transcript belongs to the family of non-coding RNAs and more clinical studies needs to be done in order to establish if this transcript could be associated as independent prognostic factor in PCa patients.

\section{Lnc-MX1-1}

Lnc-MX1-1, which is located on chromosome $21 \mathrm{q} 22.3$, consists of two exons and is $1.1 \mathrm{~kb}$ in length [70]. A study conducted by Jiang and coworkers in 2016 that assessed a cohort of 60 patients who underwent radical prostatectomies and biopsies showed that lncRNA lnc-MX1-1 is overexpressed in neoplastic tissues and cell lines derived from PCa compared to control cell lines and tissues [71]. The high expression level of lncMX1-1 is correlated with metastasis, high PSA levels and a high Gleason score. Moreover, Kaplan-Meier survival curve analyses showed that when lnc-MX1-1 is highly expressed, patients have poor prognoses compared to patients with normal lnc-MX1-1 expression. Survival analysis showed that patients with high expression of lnc-MX1-1 implicated poor recurrence free survival (RFS) [71]. This analysis showed that lnc-MX1-1 is an independent prognostic factor for biochemical relapse-free survival in PCa patients [71]. In summary, lnc-MX1-1 is a prognostic biomarker that, when combined with other biomarkers such as PSA and the PCA3 score, can be helpful in PCa diagnostics, prognostics and treatment, suggesting that a combination of genes and IncRNAs can be used in the clinic to get a prognosis panels.

\section{MALAT1}

MALAT1 (metastasis associated lung adenocarcinoma transcript 1) is a lncRNA that is approximately $8 \mathrm{~kb}$ long, localized to chromosome 11 (11q13.1) and expressed in different tissues [72]. MALAT-1 lacks a canonical polyadenylated tail, but it is stabilized through the formation of a triple helix structure at the $3^{\prime}$ end [73]. It accumulates in nuclear speckles and regulates mRNA expression through splicing and editing [74]. First descriptions of MALAT1 and its association with PCa were provided by Ren and coworkers in 2013, who observed that MALAT1 is overexpressed in tumors and different prostate cell lines [75]. Later, the same group showed that high MALAT-1 expression correlated with high Gleason score, PSA, tumor stage and castrationresistant prostate cancer (CRPC) [76]. Moreover, MALAT1 downregulation by siRNA inhibited PCa cell growth, invasion and migration and induced CRPC cell cycle arrest at the G0/G1 phase. Given the importance of MALAT1 in this study, the authors suggested that MALAT1 is a promising therapeutic target for CRPC [76]. MALAT1 is also a poor overall-survival (OS) biomarker in various other types of cancer [77], which highlights the high potential of MALAT1 as a biomarker for prognostic in PCa. Nevertheless, broader clinical studies are needed to confirm this possibility.

\section{DRAIC/PCAT29}

DRAIC (downregulated RNA in cancer) is a recently described non-coding transcript. This molecule is $1.7 \mathrm{~kb}$ long, 3'-polyadenylated, localized in the cytoplasm and originates from the $15 \mathrm{q} 23$ locus. Unlike other lncRNAs, DRAIC undergoes a splicing process from the 100-kb RNA molecule that is encoded in the 
$15 q 23$ locus to produce its final form [78]. There are other three variants of this IncRNA, but even though they have similar expression patterns compared with the canonical DRAIC, they are poorly represented in the cellular RNA pool. The same locus contains another $100-\mathrm{kb}$ non-coding sequence known as PCAT29, and although it is located 20 $\mathrm{kb}$ downstream away from DRAIC, it does not originate from the DRAIC RNA splicing process; PCAT29 is independently transcribed. Both molecules are negatively regulated by $\mathrm{AR}$, which represses their transcription, while FOXA1 and NKX3-1 promote DRAIC and PCAT29 expression [78].

DRAIC prevents epithelial cell transformation, thus inhibiting cell migration, and PCAT29 is associated with inhibition of cell migration and metastasis. For this reason, the expression of the DRAIC/PCAT29 locus is associated with a good cancer prognosis. Specifically, DRAIC expression correlates with disease-free survival (DFS) in PCa patients while PCAT-29 is associated with BCRFS [78, 79]. In the case of DRAIC, it is downregulated in prostate cancers that progress from an androgendependent phenotype (AD) to CRPC. This reduction is caused by decreased expression of FOXA1 and NKX3-1, which leads to reduced expression of DRAIC/PCAT29. The positive effects that are associated with DRAIC are not limited to one type of cancer; DRAIC expression also correlates with a good prognosis in bladder cancer, lung and stomach adenocarcinomas, renal and hepatocellular carcinomas, melanoma and low-grade glioma [78]. Thus the expression of DRAIC / PCAT-29 appears to be associated with good prognosis, which makes this pair of non-coding transcripts good candidates for their use for the prognosis of $\mathrm{PCa}$.

\section{UCA1}

Urothelial carcinoma associated 1 (UCA1), which is located on chromosome $19 \mathrm{p} 13$, consists of three exons that are spliced into three isoforms - $1.4 \mathrm{~kb}, 2.2 \mathrm{~kb}$ and $2.7 \mathrm{~kb}$ - that are subsequently polyadenylated. UCA1 was originally identified in bladder transitional carcinoma and is associated with proliferation and apoptosis. Thus, its high expression in several carcinomas was an unsurprising observation because UCA1 is frequently overexpressed in cancerous tissues relative to normal tissues [80].

The oncogenic nature of UCA1 is evident in hepatocellular carcinoma. In this carcinoma type, UCA1 acts through a long non-coding RNA-mediated sponge mechanism by directly binding to miR-216b and downregulation miR-216b expression [81]. The inhibition of miR-216b leads to activation of the FGFR1/ERK signaling pathway and to subsequent cancer progression of this cancer [81]. Another known mechanism of UCA1 is activation of Wnt, Akt or the PI3K pathway, as shown in bladder cancer [82-84]. Its role in PCa is also deleterious because it is overexpressed in the tumors relative to normal adjacent tissue, as evidenced in breast, cervical, colorectal, gastric, lung, ovarian, and thyroid cancers and in tongue and esophageal squamous carcinoma [85]. Furthermore, a high level of UCA1 expression is associated with a poor prognosis in PCa, its mean that UCA1 expression was positively associated with high gleason score, advanced TNM stage and shorter overall survival (OS) of patients [86] and recently in BCR-FS and DFS [87]. Interestingly, its inhibition may be therapeutically significant because the use of RNA interference against UCA1 inhibits proliferation and increases the proportion of apoptotic cells in vitro. This effect occurs partly through the KLF4-KRT6/ KRT13 pathway, where KLF4 is a transcription factor that is associated with differentiation and proliferation and whose expression is also significantly higher in PCa tissues than in corresponding non-tumor adjacent tissues [88].

Finally, UCA1 has been suggested as one of the important mediators of radiation response. Using a siRNA knockdown strategy, it has been demonstrated that UCA1 knockdown could improve radiosensitivity in PCa cell lines and irradiation resistance PCa cells [87]. Then, UCA1 similar to PCAT-1 may represent a molecular marker that is highly valuable for prognoses and predictions in response to the therapies used in $\mathrm{PCa}$ like radiotherapy.

\section{TRPM2-AS/TRPM2-TE}

The TRPM2 antisense (TRPM2-AS) lncRNA is encoded on chromosome 21q22.3, and as its name indicates, it is an antisense transcript of the TRPM2 (Transient Receptor Potential cation channel subfamily M member 2) gene, which encodes a voltagedependent calcium channel that is associated with cell death susceptibility [89]. The TRPM2-AS locus also encodes Tumor Enriched TRPM2 (TRPM2-TE), another lncRNA. TRPM2-TE is transcribed in opposite direction to TRPM2-AS from the same CpG island in which the TRPM2-AS promoter is located [90]. TRPM2$\mathrm{AS}$ is enriched in melanoma and $\mathrm{PCa}$, where its high expression is associated with a poor clinical outcome. Multivariate analysis also showed that the TRPM2AS was an independent predictor of OS as well as an independent predictor of RFS [90]. This is attributable to regulatory actions by TRPM2-AS on the targets of several drugs that are used to treat $\mathrm{PCa}$. For this reason, TRPM2-AS is considered a novel therapeutic target because knocking out this molecule leads to increased cell stress and apoptosis [91]. TRPM2-AS is also considered a biomarker for the early identification of an aggressive form of PCa. However, TRPM2-TE is associated with the downregulation of TRPM2 in cancer, thus avoiding the previously mentioned cell death susceptibility that is induced by the increased expression of this ion channel [90]. 


\section{PCAT-14}

PCAT-14 (Prostate Cancer Associated Transcript-14) is a prostate cancer-specific IncRNA. A study conducted in 2016 by Shukla and coworkers showed that PCAT-14 has four transcript isoforms of which the 2.3-kb variant-1 has the highest expression level [92]. The PCAT-14 is an ARregulated lncRNA that contains 4 exons and is located on chromosome 22-q11.2. This lncRNA is upregulated in $\mathrm{PCa}$ compared with its expression in normal prostate tissue, and one of the peculiarities of PCAT-14 is its inverse relationship with the Gleason score, which suggests its role as a suppressor of aggressive disease. PCAT-14 is a strong prognostic biomarker, and its expression increases significantly during the initial formation of cancer [93]. Interestingly, in PCa patients, a decrease in its expression promotes an aggressive oncogenic phenotype, and low PCAT-14 expression predicts metastatic disease [93]. In a study conducted by White et al. (2016), expression microarray from radical prostatectomy samples and clinical data were obtained from a cohort of 910 patients and showed that downregulation of PCAT-14 is associated with a greater probability of metastatic progression and expression of genes that are involved in aggressive disease [94]. These data correlate with the results of a study by Shukla et al. (2016), where a cohort of 355 patients was studied and using Cox regression analysis revealed that PCa patients with high PCAT-14 expression have better outcomes and are significantly associated with better prostate cancer specific survival (PSS), metastasis free survival (MFS), biochemical relapse-free survival (BRFS), with borderline significance for OS [92]. On the other hand, low PCAT-14 expression is associated with aggressive disease [92]. This data shows that PCAT-14 is a dual biomarker for $\mathrm{PCa}$ prognosis because its expression is high during the early stages of $\mathrm{PCa}$ while its later downregulation indicates an aggressive disease prognosis in PCa patients.

\section{DANCR}

The DANCR (Differentiation Antagonizing NonProtein Coding RNA) is a lncRNA that is localized to chromosome $4 \mathrm{q} 12$, and its length is approximately 850 bases [94]. DANCR is required for the dedifferentiation of epidermal cells and is associated with several cancers, including PCa [95]. However, its function in cancer is still under investigation. DANCR expression is high in PCa tissues compared to normal tissues. This observation is also evident in vitro, where DANCR expression is higher in a PCa cell line than in an immortalized prostate epithelial cell line [96]. According to a study conducted by Jia et al. in 2016, high DANCR expression promotes metastasis of xenografts of primary PCa patient samples in nude mice, and DANCR promotes cell migration in vitro, suggesting that DANCR may be associated with metastatic PCa [96]. In fact, the aforementioned study proposes that DANCR levels in urine samples from men with PCa should be measured to determine whether this lncRNA can be detected as a urinary biomarker for $\mathrm{PCa}$ prognosis and diagnosis. More studies using human specimens are needed to clarify the clinical relevance of DANCR in PCa. However, the data highlight DANCR as a potential biomarker for the prognosis and diagnosis of $\mathrm{PCa}$ and metastatic disease.

\section{PCAT-18}

Prostate cancer associated transcript 18, also known as PCAT-18, is a 2.5 -kb non-coding RNA with two exons and is located on chromosome 18q11.2. PCAT-18 is specifically expressed in the prostate and is upregulated in $\mathrm{PCa}$; its expression is induced indirectly by AR signaling [97]. In a study conducted by Crea et al., in 2014, RNA-Seq expression analysis was performed on paired metastatic/non-metastatic prostate cancer xenografts that were derived from clinical specimens, and the results showed that PCAT- 18 was highly upregulated [97]. This study also showed that PCAT-18 could be identified in plasma samples and that PCAT-18 expression was upregulated in metastatic tissues compared with the levels found in primary PCa samples. The authors suggest that PCAT-18 measurements in plasma may be a more accurate approach for detecting PCa and that PCAT-18 may serve as a prognostic biomarker of metastatic disease [98]. In addition, PCAT-18 has been implicated in several signaling pathways that control proliferation, invasion and metastasis suggesting that this lncRNA may be involved in cellular processes leading to the development and progression of PCa [98]. Based on these data, PCAT-18 is undoubtedly a potentially strong biomarker and due to its importance in $\mathrm{PCa}$ it is suitable for clinical approach.

\section{CCAT2}

Colon cancer-associated transcript 2 (CCAT2) is a $1.7-\mathrm{kb}$ non-coding RNA that is transcribed from the chromosome 8q24.21 region. This RNA is upregulated in colorectal cancer and other cancers [98]. In a study conducted by Zheng et al. in 2016, a qRT-PCR analysis showed that CCAT2 was highly overexpressed in $\mathrm{PCa}$ tissues compared to adjacent normal prostate tissues in 96 patients [99]. CCAT2 overexpression was also shown in two PCa cell lines, in contrast to a normal prostate cell line. These data suggest that the expression of CCAT2 may be associated with PCa pathogenesis. High expression of CCAT2 predicts poor prognosis in patients with $\mathrm{PCa}$, and high expression CCAT2 levels are associated with poor PFS and poor OS per a Kaplan-Meier analysis, suggesting a correlation between CCAT2 and PCa progression [99]. This study also showed that CCAT2 promotes the EMT and that knock down of CCAT2 inhibited cell migration 
and invasion [99]. Based on these data, CCAT2 is undoubtedly a potential gene for use as a biomarker for the prognosis and diagnosis of PCa in humans. This gene should be examined in other human samples, including the blood or urine, to determine whether this lncRNA can be used as a prognostic biomarker in $\mathrm{PCa}$.

In summary, the afore mentioned lncRNAs have been shown to be potential candidates in the field of prognostic biomarkers in PCa, even new studies continue to suggest new lncRNAs as potential prognostic biomarkers [100-102]. Currently three commercially available RNA-based genetic panels have been validated in PCa patients and are utilized in clinical practice, these includes Prolaris, Oncotype DX and Decipher [103]. Those tests can be applied to estimate disease outcome like BCR, DSS and MFS in addition to clinical parameters or clinical nomograms. Despite the great importance of these RNA-based panels in the prognosis of PCa [103], those molecular tests still have limits, moreover lncRNAs could be a solution for the limitations because they present a best tissue specific signature, that can be employed in this type of testing in combination with coding genes and epigenetic features like DNA methylation [104]. Those combinations will help to develop algorithms that can support the selection of patients that are most likely to benefit from an individualized treatment with either surgery, AR inhibitors or radiation therapy. However, future clinical trials studies are necessary, and need to focus on biological manipulation of known high-risk lncRNAs and genes to reduce the incidence of PCa.

\section{NEXT-GENERATION SEQUENCING AND LncRNAs}

Since the discovery and characterization of the first lncRNA, the field has experienced enormous growth, adding thousands of new molecules every year. This accelerated rate of discovery has been driven primarily by next-generation sequencing technologies, specifically RNA-Seq, and has allowed scientists to explore the complete transcription profile of a given sample. Using this tool, different investigators have revealed the great diversity of lncRNAs in size (>200 nt) and structure and their specific expression profiles, showing that most lncRNAs display tissue-specific expression patterns and that many are conserved in different organisms.

These studies have also highlighted a more important feature of lncRNAs, namely, their participation in several cellular functions as scaffolds for protein complexes or regulators of gene expression. Notably, these studies have shown that particular lncRNAs are deregulated in multiple disease types, including cancer.

Together with the publication of different studies that profile the expression of novel lncRNAs in a myriad of tissues and organisms, there has also been a boom in the development of databases that are designed specifically for lncRNAs. There are several databases that are dedicated to the curation of novel reported lncRNAs, including LncRNABase [105], LNCipedia [106], lncRNAdb [107], LncRNAWiki [70], NONCODE [108], TANRIC [109] and the ncRNA expression database [68]. Sequencing technology has evolved rapidly enough to allow lncRNA profiling at a single-cell resolution [110], which averts future complications due to tumor heterogeneity. Additionally, computational methods have been streamlined for the discovery of new lncRNA molecules. However, the functional characterization of the thousands of reported lncRNAs and their associations with particular disease models is a bottleneck in the field [111].

With this information, the expectations in personalized cancer treatment have flourished over the last few years. The number of lncRNAs that have been proposed as potential biomarkers in cancer is increasing every year, and several lncRNAs have already been used for sensitive and specific tests, such as the PCA3 urine test for prostate cancer [112]. This highlights the possibility of using these molecules as biomarkers or potential therapeutic targets for future individualized treatments. As mentioned before, one particular advantage of lncRNAs is their stability, which enables their detection in body fluids, including blood, saliva and urine, and subsequently facilitates patient diagnosis. This last point makes them perfect candidates for development as potential biomarkers.

However, although the cost of sequencing has steadily dropped, it is not cost-effective enough to allow sequencing of every patient to generate individual patient IncRNA profiles, especially because many lncRNAs are expressed at low levels, which require high sequencing coverage for proper evaluations. In this context, the generation of panels of the lncRNAs that are altered in particular pathologies, either by qRT-PCR, microarray or target sequencing, can potentially cut costs or provide a more straightforward method for these evaluations.

\section{LONG NON-CODING RNAs, PRECISION MEDICINE AND THERAPY}

Conventional treatments are design to treat illnesses in terms of the average patient response, assuming that one average approach fits all individuals. However, what is successful for some patients might not work for other patients. Thus, an emerging approach for disease treatment and prevention, known as precision medicine, has gained attention toward improving treatment efficacies. Precision medicine is based on knowledge of the individual variability observed in the genes, epigenetic profiles, environment and lifestyle of each person. The concept is sustained by the assumption that genetic or molecular aberrations can cause or contribute to a disease [113]. Therefore, genomic studies and related information will shed light on various questions that are associated with the 
health and disease of an individual. Genomic approaches, including DNA sequence variation, expression profiles, proteomics and metabolomics, have become valuable tools for precise disease management and prediction. However, information from an individual genome sequence and expression of associated biomarkers are essential toward establishing risk checkpoints and achieving precision therapies [114, 115].

A great challenge in cancer therapy is to design drugs that are targeted specifically to kill the tumor cells without harming the healthy cells. In order to achieve this goal, therapies must target molecules that work as drivers of tumor formation or progression, which in turn, are only or mainly expressed in the tumoral tissue and not in the non-neoplastic tissues. IncRNAs have become attractive candidates for biomarkers and precision medicine targets in cancer, because they can be specially expressed in tumor cells, as it has been reported several cancers for many lncRNAs [116-119].

Misexpression of ncRNAs has already been observed to directly lead diseases. The first report was in a patient with anemia ( $\alpha$-thalassaemia), who presented a rare chromosome rearrangement [120]. This rearrangement promoted the translocation of the promoter of LUC7L immediately downstream of the HBA2 ( $\alpha$-globin) gene resulting in the transcription of an antisense RNA. Such ncRNA mediates hypermethylation of the $\mathrm{CpG}$ island that negatively regulates $\mathrm{HBA} 2$ gene [120]. Other report shown that IncRNA (BC200), was found to be up-regulated and mislocalized in $\mathrm{AD}$ neurons of the brains of Alzheimer's disease patients an could be leading behavioral effects and be involved in the disease pathophysiology [121]. Due to this kind of reports the possibility to treat disease by targeting lncRNA seems and attractive field in therapeutics.

There are different approaches to target lncRNAs, which includes small interfering RNAs (siRNAs), RNA destabilizing elements (RDEs), Antisense Oligonucleotides (ASOs) and Ribozymes (Table 1). siRNAs have long been used to downregulate RNA level by targeting specific sequences [122, 123]. The mechanism of action of siRNAs by binding to an exact sequence of nucleotides which later promotes RNA degradations, guarantee to be highly specific. Thus, it has been employed for phase I and II trials for several diseases, for example: PF-04523655, TKM-080301, SYL040012, SYL1001, siG12D-LODER; and other for phase III trials, such as: QPI-1002, QPI-1007, and patisiran [124-127]. Recently, employing siRNA to target the lncRNA HOTAIR has been suggested to suppress the progression of endometrial carcinoma in vivo showing that targeting lncRNA as HOTAIR can be a novel therapeutic strategy for endometrial cancer. [128]. Another important example of targeting lncRNAs by siRNAs and therapy is MALAT1 where molecular evidence has established that there is a close relation between MALAT1 and drugs like enzalutamide.

Enzalutamide is a potent next-generation antiandrogen drug; it has been used for the treatment of metastatic CRPC. This drug was approved as AR signaling inhibitor by FDA to the treatment of CRPC some years ago. However, some patients have been developed resistance against this novel agent [129, 130]. In a pre-clinical study has been proposed that MALAT-1 can contributes to enzalutamide resistance in CRPC by promoting the expression of the AR splice variant ARV7 and targeting MALAT1 by siRNA can be used as new therapy to better suppress the progression in $\mathrm{PCa}$ patients [131]. Thus, targeting lncRNAs by siRNA are promising as a therapeutic strategy for different types of cancer, and might be a plausible approach for PCa.

Other method that could be applied to target lncRNAs is the use of ASOs, these oligonucleotides target primary structure of RNA, from arrange of 8 to 50 nucleotides in length. As siRNA, ASO molecules act by inhibiting translation or inducing degradation of target mRNA. The employ of ASO to therapy suggest some advantages in contrast with siRNA, because is easy to deliver to tissue, is very specific to mRNA molecules or ncRNA molecules. ASOs are the most mature antisense technology with respect to clinical application. They're many supporting evidences of its potential as anticancer drugs, due to its capacity to specifically suppress expression of genes contributing to the progression of disease like cancer. Its use in cancer therapeutics is proposed to be best if employed together, as an adjuvant with other drugs that do not target RNA molecules [132, 133].

Pre-clinical studies suggested that ASOs directed to oncogenes or enzymes or other protein that are necessary for tumor proliferation and resistance, increase the sensibility of chemotherapeutic drugs or radiation of different tumors [134, 135]. The progress of clinical application of ASOs have been completed or are in progress of Phase I or II clinical trials and in human PCa and other tumors therapy, as ISIS 3521, ISIS 5132 Oblimersen and Clusterin [136-139].

There are reports that enlighten the possible future application of antisense inhibition of lncRNA in the clinics. Again one of them is MALAT1, which has been shown to be an active player in lung cancer metastasis, and targeting MALAT1 by ASO drastically reduced metastasis formation of this tumor cells in vivo, suggesting the use of an ASO against lncRNA in lung cancer therapy [140]. Moreover, the application of antisense mechanisms against lncRNA is still in its infancy, but it proves to be an exciting field for future tumor therapy.

Another interesting approach that could be exploited for cancer therapy is based on the fact of lncRNA tissue specific expression. As it was thoroughly discussed above, many lncRNA are specifically expressed 
Table 1: IncRNAs in RNA-based therapeutics

\begin{tabular}{|c|c|c|c|c|c|}
\hline Method & IncRNA & Disease & Experimental models & Status & Reference \\
\hline siRNA & HOTAIR & Endometrium cancer & $\begin{array}{l}\text { HEC-1A and } \\
\text { Mice Xenograft }\end{array}$ & Pre-clinical & [128] \\
\hline siRNA & MALAT-1 & Prostate cancer & $\begin{array}{c}\text { C4-2 and } \\
\text { Mice Xenograft }\end{array}$ & Pre-clinical & [131] \\
\hline siRNA & NRCP & Ovarian cancer & $\begin{array}{c}\mathrm{SKOV} 3, \mathrm{~A} 2780 \text { and } \\
\text { orthotopic ovarian cancer } \\
\text { mouse }\end{array}$ & Pre-clinical & {$[147]$} \\
\hline ASO & MALAT-1 & Lung cancer & $\begin{array}{c}\text { A549 and } \\
\text { Mouse Xenograft }\end{array}$ & Pre-clinical & {$[140]$} \\
\hline $\begin{array}{l}\text { Recombinant } \\
\text { plasmid }\end{array}$ & $\begin{array}{l}\text { Promoter } \\
\text { región of } \\
\text { H19 }\end{array}$ & $\begin{array}{l}\text { Bladder, ovarian, } \\
\text { glioblastoma. }\end{array}$ & $\begin{array}{l}\text { T24P, HT-1376, ES-2, } \\
\text { SKOV-3, A172, U87, } \\
\text { GL261, nude mice. }\end{array}$ & $\begin{array}{c}\text { Clinical trials: } \\
\text { Phase I and Phase II }\end{array}$ & [142-146] \\
\hline
\end{tabular}

${ }^{*}$ The full names of the lncRNAs can be located in the text or abbreviation section.

in tumors and not in normal tissue. Therefore, the regulatory regions of IncRNA could be employed to drive the tumor specific expression of genes that could serve as targeted therapy. Since the elevated expression of the lncRNA H19 is specifically associated in many types of tumors [141]. The regulatory sequences of H19 and IGF2-P4 has been cloned in the BC-819 plasmid and conjugated with the gene for the A fragment of diphtheria toxin [141]. Such construction has been shown to inhibit tumor growth without harming normal cells. The efficacy and safety of the use of these vectors has been proven in vitro and in vivo in several types of carcinomas, including metastatic colon carcinoma, inoperable ovarian cancer, bladder carcinoma and glioblastoma [142-144]. There are already FDA approved clinical phase I and II studies of superficial bladder cancer and also for ovarian cancer $[145,146]$, where the BC-819 vector reported mild local toxicity and partial responses. It has demonstrated to be effective in patients in whom bladder or ovarian cancer showed H19 expression, in which numerous other treatments had failed. Hence, studies like the H19-DTA in cancer therapy open the door for the use of lncRNA regulatory regions and the tissue specificity of these genes to do precision medicine in different types of cancer such as PCa. Here it would be great to propose any of the previous discussed lncRNA whose regulatory regions can be use.

It is important to emphasize that our current understanding of the IncRNA world is just beginning, there is needed more studies of their function, mechanism and regulation to further apply lncRNA to cancer therapy. However current results that have been discussed above highlight the exciting new opportunities that will arise from lncRNA to cancer treatment that could greatly impact future precision medicine strategies in the future.

\section{CONCLUSIONS}

Long non-coding RNAs are new players in the field of medicine, and lncRNA-based molecular diagnostics and applications in therapy in PCa are still in their infancy. The use of lncRNAs as prognostic biomarkers will be a potential weapon for combatting the public health problem that is $\mathrm{PCa}$, because these transcript types have high tissue specificities, which can be detected using non-invasive methods, and are known to have a key role during the molecular pathogenesis of cancer. Furthermore, studies have shown that aberrant expression of lncRNAs are characteristic of different types of cancer, particularly PCa. For example, measuring the urinary levels of the PCA3 lncRNA together with PSA results in a "PCA3 score" (PROGENSA PCA3 ASSAY) where a value $<25$ is associated with a decreased risk of a positive biopsy. This PCA3 assay is the first lncRNAbased molecular diagnostic test to be approved by the FDA for use in the clinic, suggesting the importance of long non-coding transcripts in the clinic. Actually there are three RNA-based test for PCa prognosis, this kind of test can be including in the future prognosis lncRNAs in their algorithms in order to add more prognostic value in the management of PCa patients. However, centric and multicenter clinical studies with long cohorts of patients need to be performed to confirm this possibility. On the other hand, clinical research has shown that specific lncRNAs can be associated with PCa prognosis. These early studies demonstrate how lncRNAs can be combined with clinical factors to discern patient outcomes (Table 2). Thus, Non-invasive methods in combination with genes and lncRNA specific signatures will be promising to develop new tests for individualized prognostic and therapy for PCa patients. 
Table 2: Long non-coding RNAs associated to PCa prognosis

\begin{tabular}{|c|c|c|c|c|c|}
\hline IncRNA & $\begin{array}{c}\text { Genomic } \\
\text { localization }\end{array}$ & $\begin{array}{c}\text { Clinical } \\
\text { significance }\end{array}$ & $\begin{array}{c}\text { Evaluated } \\
\text { cancerous } \\
\text { sample }\end{array}$ & Effects & Reference \\
\hline PCA3 & $9 q 21-22$ & Poor prognosis & Urine & $\begin{array}{c}\text { PCA3 expression correlates with high PSA } \\
\text { level and advanced clinical stage. }\end{array}$ & {$[36,43]$} \\
\hline PCAT1 & $8 \mathrm{q} 24.21$ & Poor prognosis & Tissue & $\begin{array}{l}\text { High expression is associated with high cell } \\
\text { proliferation, high-grade localized (Gleason } \\
\text { score } \geq 7 \text { ) and metastatic PCa. Besides it is } \\
\text { associated with prostate cancer progression. }\end{array}$ & {$[47,50]$} \\
\hline SChLAP1 & $2 \mathrm{q} 31.3$ & $\begin{array}{c}\text { Aggressive } \\
\text { PCa, } \\
\text { Metastasis, } \\
\text { clinical } \\
\text { progression, } \\
\text { BCR }\end{array}$ & Tissue & $\begin{array}{l}\text { High expression is associated with a higher } \\
\text { risk of biochemical recurrence, metastasis } \\
\text { and death from PCa. It is a useful to } \\
\text { identify PCa patients at higher risk of lethal } \\
\text { progression. }\end{array}$ & {$[53,54,56]$} \\
\hline PCGEM1 & $2 \mathrm{q} 32.3$ & High risk $\mathrm{PCa}$ & $\begin{array}{l}\text { Cell lines } \\
\text { and Tissues }\end{array}$ & $\begin{array}{l}\text { Overexpression is related to high risk PCa. } \\
\text { Its lncRNA promotes cell proliferation and } \\
\text { inhibits apoptosis. }\end{array}$ & {$[58,59]$} \\
\hline ATB & $14 \mathrm{q} 11.2$ & BCR-FS & $\begin{array}{l}\text { Tissue and } \\
\text { cell lines }\end{array}$ & $\begin{array}{l}\text { High expression is related with aggressive } \\
\text { disease (high histological grade, high PSA } \\
\text { level, pathological stage, high Gleason } \\
\text { score and lymph node metastasis). }\end{array}$ & {$[63]$} \\
\hline LOC400891 & $22 q 11.2$ & BCR-FS & $\begin{array}{l}\text { Tissue and } \\
\text { cell lines }\end{array}$ & $\begin{array}{l}\text { High expression is related with } \\
\text { development of advanced prostate cancer. }\end{array}$ & {$[68,69]$} \\
\hline lnc-MX1-1 & $21 \mathrm{q} 22.3$ & RFS & $\begin{array}{l}\text { Tissue and } \\
\text { cell lines }\end{array}$ & $\begin{array}{l}\text { Overexpression is related to clinical } \\
\text { features such as high PSA, Gleason score } \\
\text { and metastasis. Knockdown in vitro } \\
\text { reduced both proliferation and invasiveness. }\end{array}$ & [71] \\
\hline MALAT-1 & $11 \mathrm{q} 13.1$ & Poor prognosis & $\begin{array}{l}\text { Urine, tissue, } \\
\text { plasma and } \\
\text { cell lines }\end{array}$ & $\begin{array}{c}\text { Overexpression in vitro of this lncRNA } \\
\text { enhances migration and metastasis. High } \\
\text { expression is related to progression of PCa } \\
\text { to CRPC and high Gleason score, PSA and } \\
\text { tumor stage. }\end{array}$ & $\begin{array}{c}{[72,75-77} \\
148]\end{array}$ \\
\hline DRAIC & $15 \mathrm{q} 23$ & DFS & $\begin{array}{l}\text { Tissue and } \\
\text { cell lines }\end{array}$ & $\begin{array}{l}\text { Downregulation of this lncRNA is related } \\
\text { to progression from androgen dependent } \\
\text { PCA to CRPC. Its promotes } \\
\text { cell proliferation but inhibits cell migration } \\
\text { and invasion. }\end{array}$ & {$[78]$} \\
\hline РCAT29 & $15 \mathrm{q} 23$ & BCR-FS & $\begin{array}{l}\text { Tissue and } \\
\text { cell lines }\end{array}$ & $\begin{array}{l}\text { Downregulation is associated with } \\
\text { poor prognostic. Knockdown increased } \\
\text { proliferation and migration of PCa cells. } \\
\text { Overexpression in vitro suppressed growth } \\
\text { and metastases of prostate tumors. }\end{array}$ & {$[78,79]$} \\
\hline UCA1 & $19 \mathrm{p} 13$ & $\begin{array}{l}\text { OS, BCR-FS } \\
\text { and DFS }\end{array}$ & $\begin{array}{l}\text { Tissue and } \\
\text { cell lines }\end{array}$ & $\begin{array}{l}\text { It is overexpressed in PCa compared to } \\
\text { normal adjacent tissue. Overexpression } \\
\text { in vitro promotes cell proliferation and } \\
\text { antiapoptotic effect. }\end{array}$ & {$[80,86-88]$} \\
\hline TRPM2-AS & $21 \mathrm{q} 22.3$ & RFS and OS & $\begin{array}{l}\text { Tissue and } \\
\text { cell lines }\end{array}$ & $\begin{array}{l}\text { Overexpression induces cell proliferation, } \\
\text { knockdown in vitro leads to apoptosis in } \\
\text { PCa cells. }\end{array}$ & {$[89,90]$} \\
\hline
\end{tabular}




\begin{tabular}{|c|c|c|c|c|c|}
\hline PCAT-14 & $22-q 11.2$ & $\begin{array}{c}\text { OS, PSS, MFS, } \\
\text { BRFS }\end{array}$ & Tissue & $\begin{array}{l}\text { It is found overexpressed in low grade } \\
\text { disease while down-regulation predicts } \\
\text { disease aggressiveness and recurrence. }\end{array}$ & {$[92,93]$} \\
\hline DANCR & $4 q 12$ & $\begin{array}{l}\text { Associated with } \\
\text { metastasis }\end{array}$ & $\begin{array}{l}\text { Tissue and } \\
\text { cell lines }\end{array}$ & $\begin{array}{l}\text { Overexpression in vitro promotes cell } \\
\text { migration, suggesting an association with } \\
\text { metastasis. }\end{array}$ & [94-96] \\
\hline PCAT-18 & $18 \mathrm{q} 11.2$ & $\begin{array}{l}\text { Associated with } \\
\text { metastasis }\end{array}$ & $\begin{array}{l}\text { Tissue and } \\
\text { plasma }\end{array}$ & $\begin{array}{l}\text { Promotes invasion, migration, and } \\
\text { proliferation of castration resistant prostate } \\
\text { cancer cells in vitro. }\end{array}$ & [97] \\
\hline CCAT2 & $8 \mathrm{q} 24$ & PFS and OS & $\begin{array}{l}\text { Tissue and } \\
\text { cell lines }\end{array}$ & $\begin{array}{c}\text { CCAT2 promotes EMT. Knockdown of } \\
\text { this lncRNA inhibited cell migration and } \\
\text { invasion. }\end{array}$ & {$[98,99]$} \\
\hline
\end{tabular}

*The full names of the lncRNAs can be located in the text or abbreviation section.

Therapies and drugs that target RNA molecules provide the basis for precision lncRNA-based cancer therapies, in particular more attention should be given in
lncRNAs associated to radiotherapy and AR inhibitors such as enzatulamide (Figure 1), because their importance that has been seen in patients with high-risk localized

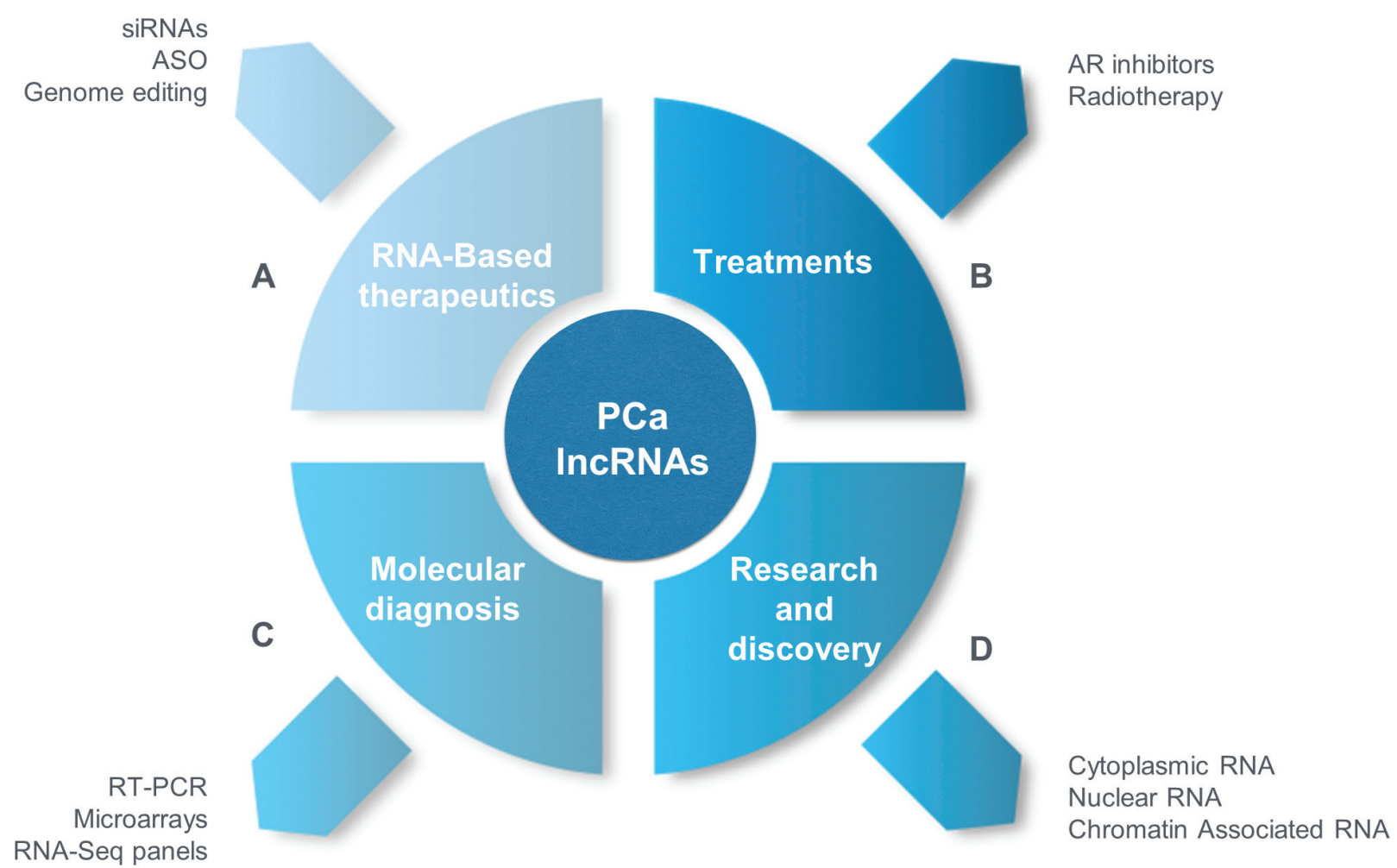

Figure 1: Long non-coding RNAs in PCa and precision medicine. (A) RNA Based-therapeutics. RNA-based therapeutics, such as siRNAs, ASOs, genome editing by ZFN and the use of regulatory sequence of lncRNAs in recombinant plasmids have great potential to target lncRNAs in PCa to generate entirely new therapeutics in PCa. (B) Treatments. Novel AR signaling inhibitors as enzalutamide has been used to aboard CRPC patients, and targeting lncRNAs trough RNA-based therapeutics strategies can be applied in order to avoid resistance to several drugs, in the future the same one could be applied to radiotherapy where lncRNAs has been proposed as predictive markers of radisensitivity [149-151]. (C) Molecular Diagnosis. lncRNAs can be used as molecular biomarkers in tumor and blood samples (invasive methods) or urine (non-invasive methods) for subsequent detection by qRT-PCR, microarrays, in situ hybridization and RNASeq panels for use in personalized treatments and prognosis (e.g., disease recurrence, disease progression, and death). (D) Research and discovery. It will be necessary to determine the different mechanisms by which lncRNAs are associated with the molecular pathogenesis of PCa; using cell lines, biopsies and primary cultures, isolated RNA can be obtained from cellular compartments (cytoplasm and nucleolus) in addition to the chromatin-associated lncRNAs. RNA-Seq will enable discoveries of new lncRNAs that are involved in the development and progression of PCa. These lncRNAs will be useful as new molecular biomarkers for PCa diagnosis, prediction and prognosis. 
$\mathrm{PCa}$, even clinical trails studies (NCT02446444) are in development to determine the effectiveness of these therapies in the outcome of patients. Thus, lncRNAs promise to be useful as molecular biomarkers for these treatments, however more efforts are required in this area because these IncRNAs are new potential novel therapeutic targets in precision medicine in $\mathrm{PCa}$.

Although there are already several transcriptomic profiles of prostate tumors, the depth of sequencing is still too low in most cases, and the detection of lowexpressing lncRNAs is compromised. Thus, a more direct profile for lncRNA studies will be necessary to compile a complete profile of the altered lncRNAs. Moreover, the high cost of this technology toward assembling the transcriptome sequence of an individual patient is an important limitation, so the future use of IncRNAs as biomarkers still resides in more punctual technologies, such as directed sequencing panels, specific microarrays, RT-qPCR analyses of specific lncRNAs and in situ hybridization. Finally, we would like to emphasize the necessity of introducing lncRNAs into clinical practice as important targets for diagnosis, prediction and prognosis in PCa because the main advantages of lncRNAs comprise their high stability in body fluids, including blood, urine or saliva and prostatic fluids; making them easy to detect in samples that are easy to obtain.

\section{Abbreviations}

PSA: prostate specific antigen; lncRNAs: long non-coding RNAs; NGS: next-generation sequencing; DRE: digital rectal examination; RNA-Seq: nextgeneration sequencing of RNA; FDA: Food and Drug Administration; PCA3: Prostate cancer gene 3; TMPRSS2: Transmembrane Protease-(global corrections) Serine 2; FGF8: fibroblast growth factor 8; IFNB1: interferon beta 1; COL18A1: collagen type XVIII alpha 1 chain; VEGFA: vascular endothelial growth factor A; $M A P 2$ K1: mitogen-activated protein kinase kinase 1; ERBB2: integrin receptor tyrosine-protein; PIK3R1: phosphoinositide-3-kinase regulatory subunit 1; TERT: telomerase reverse transcriptase; $B A D$ : $\mathrm{Bcl}-2$-associated death promoter; TNFRSF25: TNF receptor superfamily member 25; MTA2: metastasis associated 1 family member 2; PLAUR: plasminogen activator: urokinase receptor; MTSS1: metastasis suppressor protein 1; ITGB1: integrin subunit beta 1; BRCA1: breast cancer 1; ADAR: adenosine deaminases acting on RNA; PCAT-1: Prostate Cancer associated ncRNA Transcript 1; SChLAP1: second chromosome locus associated with prostate-1; BCR: biochemical recurrence; PCR: Polymerase Chain Reaction; PCGEM1: Prostate Cancer Gene Expression Marker 1; lncRNA ATB: long non-coding RNA activated by TGF- $\beta$; BCR-FS: biochemical recurrence free survival; RFS: recurrence free survival; MALAT-1: metastasis associated lung adenocarcinoma transcript 1; CRPC: castration- resistant prostate cancer; OS: overall-survival; DRAIC: Downregulated RNA in cancer; DFS: disease-free survival; AR: Androgen Receptor; AD: androgen dependent; CR: castration resistant; UCA1: Urothelial carcinoma associated 1 lncRNA; TRPM2: Transient Receptor Potential cation channel subfamily M member 2; TRPM2-AS: Transient Receptor Potential cation channel subfamily M member 2-antisense RNA; TRPM2-TE: Tumor Enriched TRPM2; PCAT-14: Prostate Cancer Associated Transcript-14; PSS: prostate cancer specific survival; MFS: metastasis free survival; BRFS: biochemical relapse-free survival: DANCR: Differentiation Antagonizing Non-Protein Coding RNA; PCAT-18: Prostate cancer associated transcript 18; CCAT2: Colon cancer-associated transcript 2; non-coding RNA: ncRNA; small interfering RNAs: siRNAs; RNA destabilizing elements: RDEs; Antisense Oligonucleotides: ASOs; qRT-PCR: quantitative Real Time-Polymerase Chain Reaction; ZFN: zinc finger nucleases; iPSC: Induced Pluripotent Stem Cells; HOTAIR: HOX transcript antisense RNA; XIST: X-inactive specific transcript; NRCP: lncRNA ceruloplasmin.

\section{ACKNOWLEDGMENTS AND FUNDING}

A-CC was supported by CONACYT-Catedras930-Identificación y validación de biomarcadores de pronóstico y predictivos en cáncer de mama and scientific research funds from the National Cancer Institute of Mexico (INCAN). D-VIA was supported by PAPIITIA207017.

\section{CONFLICTS OF INTEREST}

The authors declare no conflicts of interest.

\section{REFERENCES}

1. Cancer Facts \& Figures 2016. American Cancer Society [Internet]. [cited 2017 Mar 30]. Available 2017 Mar 30, from https://www.cancer.org/research/cancer-facts-statistics/ all-cancer-facts-figures/cancer-facts-figures-2016.html.

2. Lopes PM, Sepúlveda L, Ramos R, Sousa P. The role of transrectal ultrasound in the diagnosis of prostate cancer: new contributions. Radiol Bras. 2015; 48:7-11. https://doi. org/10.1590/0100-3984.2013.0010.

3. Merdan S, Womble PR, Miller DC, Barnett C, Ye Z, Linsell SM, Montie JE, Denton BT. Toward better use of bone scans among men with early-stage prostate cancer. Urology. 2014; 84:793-98. https://doi.org/10.1016/j. urology.2014.06.010.

4. Saini S. PSA and beyond: alternative prostate cancer biomarkers. Cell Oncol (Dordr). 2016; 39:97-106. https:// doi.org/10.1007/s13402-016-0268-6.

5. Zhao L, Yu N, Guo T, Hou Y, Zeng Z, Yang X, Hu P, Tang X, Wang J, Liu M. Tissue biomarkers for prognosis 
of prostate cancer: a systematic review and meta-analysis. Cancer Epidemiol Biomarkers Prev. 2014; 23:1047-54. https://doi.org/10.1158/1055-9965.EPI-13-0696.

6. Bhalla R, Kunju LP, Tomlins SA, Christopherson K, Cortez C, Carskadon S, Siddiqui J, Park K, Mosquera JM, Pestano GA, Rubin MA, Chinnaiyan AM, Palanisamy N. Novel dual-color immunohistochemical methods for detecting ERG-PTEN and ERG-SPINK1 status in prostate carcinoma. Mod Pathol. 2013; 26:835-48. https://doi. org/10.1038/modpathol.2012.234.

7. Sharma P, Zargar-Shoshtari K, Pow-Sang JM. Biomarkers for prostate cancer: present challenges and future opportunities. Future Sci OA. 2015; 2:FSO72. https://doi. org/10.4155/fso.15.72.

8. Zhou X, Yin C, Dang Y, Ye F, Zhang G. Identification of the long non-coding RNA H19 in plasma as a novel biomarker for diagnosis of gastric cancer. Sci Rep. 2015; 5:11516. https://doi.org/10.1038/srep11516.

9. Xie H, Ma H, Zhou D. Plasma HULC as a promising novel biomarker for the detection of hepatocellular carcinoma. BioMed Res Int. 2013; 2013:136106. https:// doi.org/10.1155/2013/136106.

10. Gupta RA, Shah N, Wang KC, Kim J, Horlings HM, Wong DJ, Tsai MC, Hung T, Argani P, Rinn JL, Wang Y, Brzoska P, Kong B, et al. Long non-coding RNA HOTAIR reprograms chromatin state to promote cancer metastasis. Nature. 2010; 464:1071-76. https://doi.org/10.1038/ nature08975.

11. Quinn JJ, Chang HY. Unique features of long non-coding RNA biogenesis and function. Nat Rev Genet. 2016; 17:4762. https://doi.org/10.1038/nrg.2015.10.

12. Devaux Y, Zangrando J, Schroen B, Creemers EE, Pedrazzini T, Chang CP, Dorn GW 2nd, Thum T, Heymans S, and Cardiolinc network. Long noncoding RNAs in cardiac development and ageing. Nat Rev Cardiol. 2015; 12:415-25. https://doi.org/10.1038/nrcardio.2015.55.

13. St Laurent G, Wahlestedt C, Kapranov P. The Landscape of long noncoding RNA classification. Trends Genet. 2015; 31:239-51. https://doi.org/10.1016/j.tig.2015.03.007.

14. Iyer MK, Niknafs YS, Malik R, Singhal U, Sahu A, Hosono Y, Barrette TR, Prensner JR, Evans JR, Zhao S, Poliakov A, Cao X, Dhanasekaran SM, et al. The landscape of long noncoding RNAs in the human transcriptome. Nat Genet. 2015; 47:199-208. https://doi.org/10.1038/ng.3192.

15. Derrien T, Johnson R, Bussotti G, Tanzer A, Djebali S, Tilgner H, Guernec G, Martin D, Merkel A, Knowles DG, Lagarde J, Veeravalli L, Ruan X, et al. The GENCODE v7 catalog of human long noncoding RNAs: analysis of their gene structure, evolution, and expression. Genome Res. 2012; 22:1775-89. https://doi.org/10.1101/gr.132159.111.

16. Cabili MN, Trapnell C, Goff L, Koziol M, Tazon-Vega B, Regev A, Rinn JL. Integrative annotation of human large intergenic noncoding RNAs reveals global properties and specific subclasses. Genes Dev. 2011; 25:1915-27. https:// doi.org/10.1101/gad.17446611.

17. Wang KC, Yang YW, Liu B, Sanyal A, CorcesZimmerman R, Chen Y, Lajoie BR, Protacio A, Flynn RA, Gupta RA, Wysocka J, Lei M, Dekker J, et al. A long noncoding RNA maintains active chromatin to coordinate homeotic gene expression. Nature. 2011; 472:120-24. https://doi.org/10.1038/nature09819.

18. Mancini-DiNardo D, Steele SJ, Ingram RS, Tilghman SM. A differentially methylated region within the gene Kcnq1 functions as an imprinted promoter and silencer. Hum Mol Genet. 2003; 12:283-94. https://doi.org/10.1093/hmg/ ddg024.

19. Autuoro JM, Pirnie SP, Carmichael GG. Long noncoding RNAs in imprinting and $\mathrm{X}$ chromosome inactivation. Biomolecules. 2014; 4:76-100. https://doi.org/10.3390/ biom 4010076 .

20. Sun M, Kraus WL. From discovery to function: the expanding roles of long noncoding RNAs in physiology and disease. Endocr Rev. 2015; 36:25-64. https://doi. org/10.1210/er.2014-1034.

21. Engreitz JM, Pandya-Jones A, McDonel P, Shishkin A, Sirokman K, Surka C, Kadri S, Xing J, Goren A, Lander ES, Plath K, Guttman M. The Xist IncRNA exploits threedimensional genome architecture to spread across the $\mathrm{X}$ chromosome. Science. 2013; 341:1237973. https://doi. org/10.1126/science. 1237973 .

22. Cao J. The functional role of long non-coding RNAs and epigenetics. Biol Proced Online. 2014; 16:11. https://doi. org/10.1186/1480-9222-16-11.

23. Song H, Sun W, Ye G, Ding X, Liu Z, Zhang S, Xia T, Xiao B, Xi Y, Guo J. Long non-coding RNA expression profile in human gastric cancer and its clinical significances. J Transl Med. 2013; 11:225. https://doi. org/10.1186/1479-5876-11-225.

24. Gu W, Gao T, Sun Y, Zheng X, Wang J, Ma J, Hu X, Li J, $\mathrm{Hu}$ M. LncRNA expression profile reveals the potential role of lncRNAs in gastric carcinogenesis. Cancer Biomark. 2015; 15:249-58. https://doi.org/10.3233/CBM-150460.

25. Wang Y, Qian CY, Li XP, Zhang Y, He H, Wang J, Chen J, Cui JJ, Liu R, Zhou H, Xiao L, Xu XJ, Zheng Y, et al. Genome-scale long noncoding RNA expression pattern in squamous cell lung cancer. Sci Rep. 2015; 5:11671. https:// doi.org/10.1038/srep11671.

26. Sartori DA, Chan DW. Biomarkers in prostate cancer: what's new? Curr Opin Oncol. 2014; 26:259-64. https:// doi.org/10.1097/CCO.0000000000000065.

27. Lorenzen JM, Schauerte C, Kölling M, Hübner A, Knapp M, Haller H, Thum T. Long Noncoding RNAs in Urine Are Detectable and May Enable Early Detection of Acute T Cell-Mediated Rejection of Renal Allografts. Clin Chem. 2015; 61:1505-14. https://doi.org/10.1373/ clinchem.2015.243600. 
28. Tang $\mathrm{H}, \mathrm{Wu} \mathrm{Z}$, Zhang J, Su B. Salivary lncRNA as a potential marker for oral squamous cell carcinoma diagnosis. Mol Med Rep. 2013; 7:761-66. https://doi. org/10.3892/mmr.2012.1254.

29. Li J, Wen W, Zhao S, Wang J, Chen J, Wang Y, Zhang Q. Prognostic role of HOTAIR in four estrogen-dependent malignant tumors: a meta-analysis. OncoTargets Ther. 2015; 8:1471-82. https://doi.org/10.2147/OTT.S84687.

30. Hua L, Wang CY, Yao KH, Chen JT, Zhang JJ, Ma WL. High expression of long non-coding RNA ANRIL is associated with poor prognosis in hepatocellular carcinoma. Int J Clin Exp Pathol. 2015; 8:3076-82.

31. Zhu L, Liu J, Ma S, Zhang S. Long Noncoding RNA MALAT-1 Can Predict Metastasis and a Poor Prognosis: a Meta-Analysis. Pathol Oncol Res. 2015; 21:1259-64. https://doi.org/10.1007/s12253-015-9960-5.

32. Sun M, Jin FY, Xia R, Kong R, Li JH, Xu TP, Liu YW, Zhang EB, Liu XH, De W. Decreased expression of long noncoding RNA GAS5 indicates a poor prognosis and promotes cell proliferation in gastric cancer. BMC Cancer. 2014; 14:319. https://doi.org/10.1186/1471-2407-14-319.

33. Zhang A, Zhang J, Kaipainen A, Lucas JM, Yang H. Long non-coding RNA: A newly deciphered "code" in prostate cancer. Cancer Lett. 2016; 375:323-30. https://doi. org/10.1016/j.canlet.2016.03.003.

34. Ma W, Chen X, Ding L, Ma J, Jing W, Lan T, Sattar H, Wei Y, Zhou F, Yuan Y. The prognostic value of long noncoding RNAs in prostate cancer: a systematic review and meta-analysis. Oncotarget. 2017; 8:57755-65. https:// doi.org/10.18632/oncotarget.17645.

35. Bussemakers MJ, van Bokhoven A, Verhaegh GW, Smit FP, Karthaus HF, Schalken JA, Debruyne FM, Ru N, Isaacs WB. DD3: a new prostate-specific gene, highly overexpressed in prostate cancer. Cancer Res. 1999; 59:5975-79.

36. Clarke RA, Zhao Z, Guo AY, Roper K, Teng L, Fang ZM, Samaratunga H, Lavin MF, Gardiner RA. New genomic structure for prostate cancer specific gene PCA3 within BMCC1: implications for prostate cancer detection and progression. PLoS One. 2009; 4:e4995. https://doi. org/10.1371/journal.pone.0004995.

37. Ferreira LB, Palumbo A, de Mello KD, Sternberg C, Caetano MS, de Oliveira FL, Neves AF, Nasciutti LE, Goulart LR, Gimba ER. PCA3 noncoding RNA is involved in the control of prostate-cancer cell survival and modulates androgen receptor signaling. BMC Cancer. 2012; 12:507. https://doi.org/10.1186/1471-2407-12-507.

38. Lemos AE, Ferreira LB, Batoreu NM, de Freitas PP, Bonamino MH, Gimba ER. PCA3 long noncoding RNA modulates the expression of key cancer-related genes in LNCaP prostate cancer cells. Tumour Biol. 2016; 37:11339-48. https://doi.org/10.1007/s13277-016-5012-3.

39. Smolle MA, Bauernhofer T, Pummer K, Calin GA, Pichler M. Current Insights into Long Non-Coding RNAs
(LncRNAs) in Prostate Cancer. Int J Mol Sci. 2017; 18:E473. https://doi.org/10.3390/ijms18020473.

40. Alshalalfa M, Verhaegh GW, Gibb EA, Santiago-Jiménez M, Erho N, Jordan J, Yousefi K, Lam LL, Kolisnik T, Chelissery J, Seiler R, Ross AE, Karnes RJ, et al. Low PCA3 expression is a marker of poor differentiation in localized prostate tumors: exploratory analysis from 12,076 patients. Oncotarget. 2017; 8:50804-13. https://doi. org/10.18632/oncotarget.15133.

41. Auprich M, Chun FK, Ward JF, Pummer K, Babaian R, Augustin H, Luger F, Gutschi S, Budäus L, Fisch M, Huland H, Graefen M, Haese A. Critical assessment of preoperative urinary prostate cancer antigen 3 on the accuracy of prostate cancer staging. Eur Urol. 2011; 59:96105. https://doi.org/10.1016/j.eururo.2010.10.024.

42. Ploussard G, Durand X, Xylinas E, Moutereau S, Radulescu C, Forgue A, Nicolaiew N, Terry S, Allory Y, Loric S, Salomon L, Vacherot F, de la Taille A. Prostate cancer antigen 3 score accurately predicts tumour volume and might help in selecting prostate cancer patients for active surveillance. Eur Urol. 2011; 59:422-29. https://doi. org/10.1016/j.eururo.2010.11.044.

43. Wei W, Leng J, Shao H, Wang W. High PCA3 scores in urine correlate with poor-prognosis factors in prostate cancer patients. Int J Clin Exp Med. 2015; 8:16606-12.

44. Clinical Evaluation of the PROGENSA(Registered Trademark) Prostate Cancer Gene 3 (PCA3) Assay in Men With a Previous Negative Biopsy Result. ClinicalTrials.gov [Internet]. [cited 2017 Apr 4]. Available 2017 Apr 4, from https:/clinicaltrials.gov/ct2/show/ NCT01024959? term=pca3\&rank=1.

45. Shen X, Zhang Y, Wu X, Guo Y, Shi W, Qi J, Cong H, Wang $\mathrm{X}, \mathrm{Wu} \mathrm{X}, \mathrm{Ju} \mathrm{S}$. Upregulated lncRNA-PCAT1 is closely related to clinical diagnosis of multiple myeloma as a predictive biomarker in serum. Cancer Biomark. 2017; 18:257-63. https://doi.org/10.3233/CBM-160158.

46. Zhang D, Cao J, Zhong Q, Zeng L, Cai C, Lei L, Zhang W, Liu F. Long noncoding RNA PCAT-1 promotes invasion and metastasis via the miR-129-5p-HMGB1 signaling pathway in hepatocellular carcinoma. Biomed Pharmacother. 2017; 95:1187-93. https://doi.org/10.1016/j.biopha.2017.09.045.

47. Prensner JR, Iyer MK, Balbin OA, Dhanasekaran SM, Cao Q, Brenner JC, Laxman B, Asangani IA, Grasso CS, Kominsky HD, Cao X, Jing X, Wang X, et al. Transcriptome sequencing across a prostate cancer cohort identifies PCAT-1, an unannotated lincRNA implicated in disease progression. Nat Biotechnol. 2011; 29:742-49. https://doi. org/10.1038/nbt.1914.

48. Prensner JR, Chen W, Iyer MK, Cao Q, Ma T, Han S, Sahu A, Malik R, Wilder-Romans K, Navone N, Logothetis CJ, Araujo JC, Pisters LL, et al. PCAT-1, a long noncoding RNA, regulates BRCA2 and controls homologous recombination in cancer. Cancer Res. 2014; 74:1651-60. https://doi.org/10.1158/0008-5472.CAN-13-3159. 
49. Prensner JR, Chen W, Han S, Iyer MK, Cao Q, Kothari V, Evans JR, Knudsen KE, Paulsen MT, Ljungman M, Lawrence TS, Chinnaiyan AM, Feng FY. The long noncoding RNA PCAT-1 promotes prostate cancer cell proliferation through cMyc. Neoplasia. 2014; 16:900-08. https://doi.org/10.1016/j.neo.2014.09.001.

50. Shi WH, Wu QQ, Li SQ, Yang TX, Liu ZH, Tong YS, Tuo L, Wang S, Cao XF. Upregulation of the long noncoding RNA PCAT-1 correlates with advanced clinical stage and poor prognosis in esophageal squamous carcinoma. Tumour Biol. 2015; 36:2501-07. https://doi. org/10.1007/s13277-014-2863-3.

51. Ge X, Chen Y, Liao X, Liu D, Li F, Ruan H, Jia W. Overexpression of long noncoding RNA PCAT-1 is a novel biomarker of poor prognosis in patients with colorectal cancer. Med Oncol. 2013; 30:588. https://doi.org/10.1007/ s12032-013-0588-6.

52. Yan TH, Yang H, Jiang JH, Lu SW, Peng CX, Que HX, Lu WL, Mao JF. Prognostic significance of long noncoding RNA PCAT-1 expression in human hepatocellular carcinoma. Int J Clin Exp Pathol. 2015; 8:4126-31.

53. Prensner JR, Iyer MK, Sahu A, Asangani IA, Cao Q, Patel L, Vergara IA, Davicioni E, Erho N, Ghadessi M, Jenkins RB, Triche TJ, Malik R, et al. The long noncoding RNA SChLAP1 promotes aggressive prostate cancer and antagonizes the SWI/SNF complex. Nat Genet. 2013; 45:1392-98. https://doi.org/10.1038/ng.2771.

54. Prensner JR, Zhao S, Erho N, Schipper M, Iyer MK, Dhanasekaran SM, Magi-Galluzzi C, Mehra R, Sahu A, Siddiqui J, Davicioni E, Den RB, Dicker AP, et al. RNA biomarkers associated with metastatic progression in prostate cancer: a multi-institutional high-throughput analysis of SChLAP1. Lancet Oncol. 2014; 15:1469-80. https://doi.org/10.1016/S1470-2045(14)71113-1.

55. Böttcher R, Hoogland AM, Dits N, Verhoef EI, Kweldam C, Waranecki P, Bangma CH, van Leenders GJ, Jenster G. Novel long non-coding RNAs are specific diagnostic and prognostic markers for prostate cancer. Oncotarget. 2015; 6:4036-50. https://doi.org/10.18632/oncotarget.2879.

56. Mehra R, Shi Y, Udager AM, Prensner JR, Sahu A, Iyer MK, Siddiqui J, Cao X, Wei J, Jiang H, Feng FY, Chinnaiyan AM. A novel RNA in situ hybridization assay for the long noncoding RNA SChLAP1 predicts poor clinical outcome after radical prostatectomy in clinically localized prostate cancer. Neoplasia. 2014; 16:1121-27. https://doi.org/10.1016/j.neo.2014.11.006.

57. Mehra R, Udager AM, Ahearn TU, Cao X, Feng FY, Loda M, Petimar JS, Kantoff P, Mucci LA, Chinnaiyan AM. Overexpression of the Long Non-coding RNA SChLAP1 Independently Predicts Lethal Prostate Cancer. Eur Urol. 2016; 70:549-52. https://doi.org/10.1016/j. eururo.2015.12.003.

58. Srikantan V, Zou Z, Petrovics G, Xu L, Augustus M, Davis L, Livezey JR, Connell T, Sesterhenn IA, Yoshino K, Buzard GS, Mostofi FK, McLeod DG, et al. PCGEM1, a prostate-specific gene, is overexpressed in prostate cancer. Proc Natl Acad Sci USA. 2000; 97:12216-21. https://doi. org/10.1073/pnas.97.22.12216.

59. Petrovics G, Zhang W, Makarem M, Street JP, Connelly R, Sun L, Sesterhenn IA, Srikantan V, Moul JW, Srivastava S. Elevated expression of PCGEM1, a prostate-specific gene with cell growth-promoting function, is associated with high-risk prostate cancer patients. Oncogene. 2004; 23:60511. https://doi.org/10.1038/sj.onc.1207069.

60. Parolia A, Crea F, Xue H, Wang Y, Mo F, Ramnarine VR, Liu HH, Lin D, Saidy NR, Clermont PL, Cheng H, Collins C, Wang Y, Helgason CD. The long non-coding RNA PCGEM1 is regulated by androgen receptor activity in vivo. Mol Cancer. 2015; 14:46. https://doi.org/10.1186/ s12943-015-0314-4.

61. Yang L, Lin C, Jin C, Yang JC, Tanasa B, Li W, Merkurjev D, Ohgi KA, Meng D, Zhang J, Evans CP, Rosenfeld MG. lncRNA-dependent mechanisms of androgen-receptorregulated gene activation programs. Nature. 2013; 500:598602. https://doi.org/10.1038/nature12451.

62. Prensner JR, Sahu A, Iyer MK, Malik R, Chandler B, Asangani IA, Poliakov A, Vergara IA, Alshalalfa M, Jenkins RB, Davicioni E, Feng FY, Chinnaiyan AM. The IncRNAs PCGEM1 and PRNCR1 are not implicated in castration resistant prostate cancer. Oncotarget. 2014; 5:1434-38. https://doi.org/10.18632/oncotarget.1846.

63. Xu S, Yi XM, Tang CP, Ge JP, Zhang ZY, Zhou WQ. Long non-coding RNA ATB promotes growth and epithelialmesenchymal transition and predicts poor prognosis in human prostate carcinoma. Oncol Rep. 2016; 36:10-22. https://doi.org/10.3892/or.2016.4791.

64. Yuan JH, Yang F, Wang F, Ma JZ, Guo YJ, Tao QF, Liu F, Pan W, Wang TT, Zhou CC, Wang SB, Wang YZ, Yang $\mathrm{Y}$, et al. A long noncoding RNA activated by TGF- $\beta$ promotes the invasion-metastasis cascade in hepatocellular carcinoma. Cancer Cell. 2014; 25:666-81. https://doi. org/10.1016/j.ccr.2014.03.010.

65. Ke L, Xu SB, Wang J, Jiang XL, Xu MQ. High expression of long non-coding RNA ATB indicates a poor prognosis and regulates cell proliferation and metastasis in non-small cell lung cancer. Clin Transl Oncol. 2017; 19:599-605. https://doi.org/10.1007/s12094-016-1572-3.

66. Qu S, Yang X, Song W, Sun W, Li X, Wang J, Zhong Y, Shang R, Ruan B, Zhang Z, Zhang X, Li H. Downregulation of IncRNA-ATB correlates with clinical progression and unfavorable prognosis in pancreatic cancer. Tumour Biol. 2016; 37:3933-38. https://doi.org/10.1007/ s13277-015-4252-y.

67. Saito T, Kurashige J, Nambara S, Komatsu H, Hirata H, Ueda M, Sakimura S, Uchi R, Takano Y, Shinden Y, Iguchi T, Eguchi H, Ehata S, et al. A Long Non-coding RNA Activated by Transforming Growth Factor- $\beta$ is an Independent Prognostic Marker of Gastric Cancer. Ann Surg Oncol. 2015; 22:S915-22. https://doi.org/10.1245/ s10434-015-4554-8. 
68. Dinger ME, Pang KC, Mercer TR, Crowe ML, Grimmond SM, Mattick JS. NRED: a database of long noncoding RNA expression. Nucleic Acids Res. 2009; 37:D122-26. https://doi.org/10.1093/nar/gkn617.

69. Wang J, Cheng G, Li X, Pan Y, Qin C, Yang H, Hua L, Wang Z. Overexpression of long non-coding RNA LOC400891 promotes tumor progression and poor prognosis in prostate cancer. Tumour Biol. 2016; 37:9603-13. https://doi.org/10.1007/s13277-016-4847-y.

70. Ma L, Li A, Zou D, Xu X, Xia L, Yu J, Bajic VB, Zhang Z. LncRNAWiki: harnessing community knowledge in collaborative curation of human long non-coding RNAs. Nucleic Acids Res. 2015; 43:D187-92. https://doi. org/10.1093/nar/gku1167.

71. Jiang CY, Gao Y, Wang XJ, Ruan Y, Bei XY, Wang XH, Jing YF, Zhao W, Jiang Q, Li J, Han BM, Xia SJ, Zhao FJ. Long non-coding RNA lnc-MX1-1 is associated with poor clinical features and promotes cellular proliferation and invasiveness in prostate cancer. Biochem Biophys Res Commun. 2016; 470:721-27. https://doi.org/10.1016/j. bbrc.2016.01.056.

72. Ji P, Diederichs S, Wang W, Böing S, Metzger R, Schneider PM, Tidow N, Brandt B, Buerger H, Bulk E, Thomas M, Berdel WE, Serve H, Müller-Tidow C. MALAT-1, a novel noncoding RNA, and thymosin beta4 predict metastasis and survival in early-stage non-small cell lung cancer. Oncogene. 2003; 22:8031-41. https://doi. org/10.1038/sj.onc.1206928.

73. Wilusz JE, JnBaptiste CK, Lu LY, Kuhn CD, Joshua-Tor L, Sharp PA. A triple helix stabilizes the $3^{\prime}$ ends of long noncoding RNAs that lack poly(A) tails. Genes Dev. 2012; 26:2392-407. https://doi.org/10.1101/gad.204438.112.

74. Wilusz JE, Freier SM, Spector DL. 3' end processing of a long nuclear-retained noncoding RNA yields a tRNA-like cytoplasmic RNA. Cell. 2008; 135:919-32. https://doi. org/10.1016/j.cell.2008.10.012.

75. Ren S, Wang F, Shen J, Sun Y, Xu W, Lu J, Wei M, Xu C, Wu C, Zhang Z, Gao X, Liu Z, Hou J, et al. Long noncoding RNA metastasis associated in lung adenocarcinoma transcript 1 derived miniRNA as a novel plasmabased biomarker for diagnosing prostate cancer. Eur J Cancer. 2013; 49:2949-59. https://doi.org/10.1016/j. ejca.2013.04.026.

76. Ren S, Liu Y, Xu W, Sun Y, Lu J, Wang F, Wei M, Shen J, Hou J, Gao X, Xu C, Huang J, Zhao Y, Sun Y. Long noncoding RNA MALAT-1 is a new potential therapeutic target for castration resistant prostate cancer. J Urol. 2013; 190:2278-87. https://doi.org/10.1016/j.juro.2013.07.001.

77. Wei Y, Niu B. Role of MALAT1 as a Prognostic Factor for Survival in Various Cancers: A Systematic Review of the Literature with Meta-Analysis. Dis Markers. 2015; 2015:164635. https://doi.org/10.1155/2015/164635.

78. Sakurai K, Reon BJ, Anaya J, Dutta A. The lncRNA DRAIC/PCAT29 Locus Constitutes a Tumor-Suppressive
Nexus. Mol Cancer Res. 2015; 13:828-38. https://doi. org/10.1158/1541-7786.MCR-15-0016-T.

79. Malik R, Patel L, Prensner JR, Shi Y, Iyer MK, Subramaniyan S, Carley A, Niknafs YS, Sahu A, Han S, Ma T, Liu M, Asangani IA, et al. The lncRNA PCAT29 inhibits oncogenic phenotypes in prostate cancer. Mol Cancer Res. 2014; 12:1081-87. https://doi. org/10.1158/1541-7786.MCR-14-0257.

80. Xue M, Chen W, Li X. Urothelial cancer associated 1: a long noncoding RNA with a crucial role in cancer. J Cancer Res Clin Oncol. 2016; 142:1407-19. https://doi. org/10.1007/s00432-015-2042-y.

81. Wang F, Ying HQ, He BS, Pan YQ, Deng QW, Sun HL, Chen J, Liu X, Wang SK. Upregulated IncRNA-UCA1 contributes to progression of hepatocellular carcinoma through inhibition of miR-216b and activation of FGFR1/ ERK signaling pathway. Oncotarget. 2015; 6:7899-917. https://doi.org/10.18632/oncotarget.3219.

82. Yang C, Li X, Wang Y, Zhao L, Chen W. Long non-coding RNA UCA1 regulated cell cycle distribution via CREB through PI3-K dependent pathway in bladder carcinoma cells. Gene. 2012; 496:8-16. https://doi.org/10.1016/j. gene.2012.01.012.

83. Wu W, Zhang S, Li X, Xue M, Cao S, Chen W. Ets-2 regulates cell apoptosis via the Akt pathway, through the regulation of urothelial cancer associated 1, a long noncoding RNA, in bladder cancer cells. PLoS One. 2013; 8:e73920. https://doi.org/10.1371/journal.pone.0073920.

84. Fan Y, Shen B, Tan M, Mu X, Qin Y, Zhang F, Liu Y. Long non-coding RNA UCA1 increases chemoresistance of bladder cancer cells by regulating Wnt signaling. FEBS J. 2014; 281:1750-58. https://doi.org/10.1111/febs.12737.

85. Wang H, Guan Z, He K, Qian J, Cao J, Teng L. LncRNA UCA1 in anti-cancer drug resistance. Oncotarget. 2017; 8:64638-50. https://doi.org/10.18632/oncotarget.18344.

86. Zhang S, Dong X, Ji T, Chen G, Shan L. Long non-coding RNA UCA1 promotes cell progression by acting as a competing endogenous RNA of ATF2 in prostate cancer. Am J Transl Res. 2017; 9:366-75.

87. Fotouhi Ghiam A, Taeb S, Huang X, Huang V, Ray J, Scarcello S, Hoey C, Jahangiri S, Fokas E, Loblaw A, Bristow RG, Vesprini D, Boutros P, Liu SK. Long non-coding RNA urothelial carcinoma associated 1 (UCA1) mediates radiation response in prostate cancer. Oncotarget. 2017; 8:4668-89. https://doi.org/10.18632/ oncotarget. 13576.

88. Na XY, Liu ZY, Ren PP, Yu R, Shang XS. Long non-coding RNA UCA1 contributes to the progression of prostate cancer and regulates proliferation through KLF4-KRT6/13 signaling pathway. Int J Clin Exp Med. 2015; 8:12609-16.

89. Orfanelli U, Wenke AK, Doglioni C, Russo V, Bosserhoff AK, Lavorgna G. Identification of novel sense and antisense transcription at the TRPM2 locus in cancer. 
Cell Res. 2008; 18:1128-40. https://doi.org/10.1038/ cr.2008.296.

90. Orfanelli U, Jachetti E, Chiacchiera F, Grioni M, Brambilla P, Briganti A, Freschi M, Martinelli-Boneschi F, Doglioni C, Montorsi F, Bellone M, Casari G, Pasini D, Lavorgna G. Antisense transcription at the TRPM2 locus as a novel prognostic marker and therapeutic target in prostate cancer. Oncogene. 2015; 34:2094-102. https://doi. org/10.1038/onc.2014.144.

91. Lavorgna G, Chiacchiera F, Briganti A, Montorsi F, Pasini D, Salonia A. Expression-profiling of apoptosis induced by ablation of the long ncRNA TRPM2-AS in prostate cancer cell. Genom Data. 2014; 3:4-5. https://doi. org/10.1016/j.gdata.2014.10.020

92. Shukla S, Zhang X, Niknafs YS, Xiao L, Mehra R, Cieślik M, Ross A, Schaeffer E, Malik B, Guo S, Freier SM, Bui $\mathrm{HH}$, Siddiqui J, et al. Identification and Validation of PCAT14 as Prognostic Biomarker in Prostate Cancer. Neoplasia. 2016; 18:489-99. https://doi.org/10.1016/j. neo.2016.07.001.

93. White NM, Zhao SG, Zhang J, Rozycki EB, Dang HX, McFadden SD, Eteleeb AM, Alshalalfa M, Vergara IA, Erho N, Arbeit JM, Karnes RJ, Den RB, et al. Multiinstitutional Analysis Shows that Low PCAT-14 Expression Associates with Poor Outcomes in Prostate Cancer. Eur Urol. 2017; 71:257-66. https://doi.org/10.1016/j. eururo.2016.07.012.

94. Kretz M, Webster DE, Flockhart RJ, Lee CS, Zehnder A, Lopez-Pajares V, Qu K, Zheng GX, Chow J, Kim GE, Rinn JL, Chang HY, Siprashvili Z, Khavari PA. Suppression of progenitor differentiation requires the long noncoding RNA ANCR. Genes Dev. 2012; 26:338-43. https://doi. org/10.1101/gad.182121.111.

95. Liu Y, Zhang M, Liang L, Li J, Chen YX. Over-expression of IncRNA DANCR is associated with advanced tumor progression and poor prognosis in patients with colorectal cancer. Int J Clin Exp Pathol. 2015; 8:11480-84.

96. Jia J, Li F, Tang XS, Xu S, Gao Y, Shi Q, Guo W, Wang X, He D, Guo P. Long noncoding RNA DANCR promotes invasion of prostate cancer through epigenetically silencing expression of TIMP2/3. Oncotarget. 2016; 7:37868-81. https://doi.org/10.18632/oncotarget.9350.

97. Crea F, Watahiki A, Quagliata L, Xue H, Pikor L, Parolia A, Wang Y, Lin D, Lam WL, Farrar WL, Isogai T, Morant R, Castori-Eppenberger $\mathrm{S}$, et al. Identification of a long noncoding RNA as a novel biomarker and potential therapeutic target for metastatic prostate cancer. Oncotarget. 2014; 5:764-74. https://doi.org/10.18632/oncotarget.1769.

98. Ling H, Spizzo R, Atlasi Y, Nicoloso M, Shimizu M, Redis RS, Nishida N, Gafà R, Song J, Guo Z, Ivan C, Barbarotto E, De Vries I, et al. CCAT2, a novel noncoding RNA mapping to $8 \mathrm{q} 24$, underlies metastatic progression and chromosomal instability in colon cancer. Genome Res. 2013; 23:1446-61. https://doi.org/10.1101/gr.152942.112.
99. Zheng J, Zhao S, He X, Zheng Z, Bai W, Duan Y, Cheng S, Wang J, Liu X, Zhang G. The up-regulation of long non-coding RNA CCAT2 indicates a poor prognosis for prostate cancer and promotes metastasis by affecting epithelial-mesenchymal transition. Biochem Biophys Res Commun. 2016; 480:508-14. https://doi.org/10.1016/j. bbrc.2016.08.120.

100. Wu J, Cheng G, Zhang C, Zheng Y, Xu H, Yang H, Hua L. Long noncoding RNA LINC01296 is associated with poor prognosis in prostate cancer and promotes cancercell proliferation and metastasis. OncoTargets Ther. 2017; 10:1843-52. https://doi.org/10.2147/OTT.S129928.

101. Zhao R, Sun F, Bei X, Wang X, Zhu Y, Jiang C, Zhao F, Han B, Xia S. Upregulation of the long non-coding RNA FALEC promotes proliferation and migration of prostate cancer cell lines and predicts prognosis of PCa patients. Prostate. 2017; 77:1107-17. https://doi.org/10.1002/ pros. 23367.

102. Huang TB, Dong CP, Zhou GC, Lu SM, Luan Y, Gu X, Liu L, Ding XF. A potential panel of four-long noncoding RNA signature in prostate cancer predicts biochemical recurrence-free survival and disease-free survival. Int Urol Nephrol. 2017; 49:825-35. https://doi.org/10.1007/ s11255-017-1536-8.

103. Boström PJ, Bjartell AS, Catto JW, Eggener SE, Lilja H, Loeb S, Schalken J, Schlomm T, Cooperberg MR. Genomic Predictors of Outcome in Prostate Cancer. Eur Urol. 2015; 68:1033-44. https://doi.org/10.1016/j.eururo.2015.04.008.

104. Costa-Pinheiro P, Montezuma D, Henrique R, Jerónimo C. Diagnostic and prognostic epigenetic biomarkers in cancer. Epigenomics. 2015; 7:1003-15. https://doi.org/10.2217/ epi.15.56.

105. Li JH, Liu S, Zhou H, Qu LH, Yang JH. starBase v2.0: decoding miRNA-ceRNA, miRNA-ncRNA and proteinRNA interaction networks from large-scale CLIP-Seq data. Nucleic Acids Res. 2014; 42:D92-97. https://doi. org/10.1093/nar/gkt1248.

106. Volders PJ, Helsens K, Wang X, Menten B, Martens L, Gevaert K, Vandesompele J, Mestdagh P. LNCipedia: a database for annotated human IncRNA transcript sequences and structures. Nucleic Acids Res. 2013; 41:D246-51. https://doi.org/10.1093/nar/gks915.

107. Quek XC, Thomson DW, Maag JL, Bartonicek N, Signal B, Clark MB, Gloss BS, Dinger ME. lncRNAdb v2.0: expanding the reference database for functional long noncoding RNAs. Nucleic Acids Res. 2015; 43:D168-73. https://doi.org/10.1093/nar/gku988.

108. Zhao Y, Li H, Fang S, Kang Y, Wu W, Hao Y, Li Z, Bu D, Sun N, Zhang MQ, Chen R. NONCODE 2016: an informative and valuable data source of long non-coding RNAs. Nucleic Acids Res. 2016; 44:D203-08. https://doi. org/10.1093/nar/gkv1252.

109. Li J, Han L, Roebuck P, Diao L, Liu L, Yuan Y, Weinstein JN, Liang H. TANRIC: An Interactive Open Platform to Explore the Function of lncRNAs in Cancer. Cancer Res. 
2015; 75:3728-37. https://doi.org/10.1158/0008-5472. CAN-15-0273.

110. Kim DH, Marinov GK, Pepke S, Singer ZS, He P, Williams B, Schroth GP, Elowitz MB, Wold BJ. Single-cell transcriptome analysis reveals dynamic changes in lncRNA expression during reprogramming. Cell Stem Cell. 2015; 16:88-101. https://doi.org/10.1016/j.stem.2014.11.005.

111. Signal B, Gloss BS, Dinger ME. Computational Approaches for Functional Prediction and Characterisation of Long Noncoding RNAs. Trends Genet. 2016; 32:620-37. https:// doi.org/10.1016/j.tig.2016.08.004.

112. Cui Y, Cao W, Li Q, Shen H, Liu C, Deng J, Xu J, Shao Q. Evaluation of prostate cancer antigen 3 for detecting prostate cancer: a systematic review and meta-analysis. Sci Rep. 2016; 6:25776. https://doi.org/10.1038/srep25776.

113. Rubin EH, Allen JD, Nowak JA, Bates SE. Developing precision medicine in a global world. Clin Cancer Res. 2014; 20:1419-27. https://doi.org/10.1158/1078-0432. CCR-14-0091.

114. Ginsburg GS, Willard HF. Genomic and personalized medicine: foundations and applications. Transl Res. 2009; 154:277-87. https://doi.org/10.1016/j.trsl.2009.09.005.

115. Hessels D, Klein Gunnewiek JM, van Oort I, Karthaus HF, van Leenders GJ, van Balken B, Kiemeney LA, Witjes JA, Schalken JA. DD3(PCA3)-based molecular urine analysis for the diagnosis of prostate cancer. Eur Urol. 2003; 44:8 15. https://doi.org/10.1016/S0302-2838(03)00201-X.

116. Scaiewicz V, Sorin V, Fellig Y, Birman T, Mizrahi A, Galula J, Abu-lail R, Shneider T, Ohana P, Buscail L, Hochberg A, Czerniak A. Use of H19 Gene Regulatory Sequences in DNA-Based Therapy for Pancreatic Cancer. J Oncol. 2010; 2010:178174. http://dx.doi. org/10.1155/2010/178174.

117. Mourtada-Maarabouni M, Pickard MR, Hedge VL, Farzaneh F, Williams GT. GAS5, a non-protein-coding RNA, controls apoptosis and is downregulated in breast cancer. Oncogene. 2009; 28:195-208. https://doi.org/10.1038/onc.2008.373.

118. Li L, Dang Q, Xie H, Yang Z, He D, Liang L, Song W, Yeh S, Chang C. Infiltrating mast cells enhance prostate cancer invasion via altering LncRNA-HOTAIR/PRC2androgen receptor (AR)-MMP9 signals and increased stem/ progenitor cell population. Oncotarget. 2015; 6:14179-90. https://doi.org/10.18632/oncotarget.3651.

119. Pickard MR, Williams GT. The hormone response element mimic sequence of GAS5 lncRNA is sufficient to induce apoptosis in breast cancer cells. Oncotarget. 2016; 7:10104 16. https://doi.org/10.18632/oncotarget.7173.

120. Tufarelli C, Stanley JA, Garrick D, Sharpe JA, Ayyub H, Wood WG, Higgs DR. Transcription of antisense RNA leading to gene silencing and methylation as a novel cause of human genetic disease. Nat Genet. 2003; 34:157-65. https://doi.org/10.1038/ng1157.
121. Mus E, Hof PR, Tiedge H. Dendritic BC200 RNA in aging and in Alzheimer's disease. Proc Natl Acad Sci USA. 2007; 104:10679-84. https://doi.org/10.1073/pnas.0701532104.

122. Mello CC, Conte D Jr. Revealing the world of RNA interference. Nature. 2004; 431:338-42. https://doi. org/10.1038/nature02872.

123. Tomari Y, Zamore PD. Perspective: machines for RNAi. Genes Dev. 2005; 19:517-29. https://doi.org/10.1101/ gad.1284105.

124. Coelho T, Adams D, Silva A, Lozeron P, Hawkins PN, Mant T, Perez J, Chiesa J, Warrington S, Tranter E, Munisamy M, Falzone R, Harrop J, et al. Safety and efficacy of RNAi therapy for transthyretin amyloidosis. N Engl J Med. 2013; 369:819-29. https://doi.org/10.1056/ NEJMoa1208760.

125. Gonzalez V, Palumaa K, Turman K, Muñoz FJ, Jordan J, García J, Ussa F, Antón A, Gutierrez E, Moreno-Montanes J. Phase 2 of bamosiran (SYL040012), a novel RNAi based compound for the treatment of increased intraocular pressure associated to glaucoma. Invest Ophthalmol Vis Sci. 2014; 55:564.

126. Nguyen QD, Schachar RA, Nduaka CI, Sperling M, Basile AS, Klamerus KJ, Chi-Burris K, Yan E, Paggiarino DA, Rosenblatt I, Khan A, Aitchison R, Erlich SS, and PF-04523655 Study Group. Phase 1 dose-escalation study of a siRNA targeting the RTP801 gene in age-related macular degeneration patients. Eye (Lond). 2012; 26:1099105. https://doi.org/10.1038/eye.2012.106.

127. Titze-de-Almeida R, David C, Titze-de-Almeida SS. The Race of 10 Synthetic RNAi-Based Drugs to the Pharmaceutical Market. Pharm Res. 2017; 34:1339-63. https://doi.org/10.1007/s11095-017-2134-2.

128. Huang J, Ke P, Guo L, Wang W, Tan H, Liang Y, Yao S. Lentivirus-mediated RNA interference targeting the long noncoding RNA HOTAIR inhibits proliferation and invasion of endometrial carcinoma cells in vitro and in vivo. Int J Gynecol Cancer. 2014; 24:635-42. https://doi. org/10.1097/IGC.0000000000000121.

129. Schalken J, Fitzpatrick JM. Enzalutamide: targeting the androgen signalling pathway in metastatic castrationresistant prostate cancer. BJU Int. 2016; 117:215-25. https://doi.org/10.1111/bju.13123.

130. Shore N, Heidenreich A, Saad F. Predicting Response and Recognizing Resistance: Improving Outcomes in Patients With Castration-resistant Prostate Cancer. Urology. 2017; 109:6-18. https://doi.org/10.1016/j.urology.2017.04.062.

131. Wang R, Sun Y, Li L, Niu Y, Lin W, Lin C, Antonarakis ES, Luo J, Yeh S, Chang C. Preclinical Study using Malat1 Small Interfering RNA or Androgen Receptor Splicing Variant 7 Degradation Enhancer ASC-J9 ${ }^{\circledR}$ to Suppress Enzalutamide-resistant Prostate Cancer Progression. Eur Urol. 2017; 72:835-44. https://doi.org/10.1016/j. eururo.2017.04.005. 
132. Jason TL, Koropatnick J, Berg RW. Toxicology of antisense therapeutics. Toxicol Appl Pharmacol. 2004; 201:66-83. https://doi.org/10.1016/j.taap.2004.04.017.

133. Rayburn ER, Zhang R. Antisense, RNAi, and gene silencing strategies for therapy: mission possible or impossible? Drug Discov Today. 2008; 13:513-21. https://doi.org/10.1016/j. drudis.2008.03.014.

134. Mu Z, Hachem P, Hensley H, Stoyanova R, Kwon HW, Hanlon AL, Agrawal S, Pollack A. Antisense MDM2 enhances the response of androgen insensitive human prostate cancer cells to androgen deprivation in vitro and in vivo. Prostate. 2008; 68:599-609. https://doi.org/10.1002/ pros. 20731.

135. Geary RS. Antisense oligonucleotide pharmacokinetics and metabolism. Expert Opin Drug Metab Toxicol. 2009; 5:381-91. https://doi.org/10.1517/17425250902877680.

136. Zhang Q, Zhou W, Kundu S, Jang TL, Yang X, Pins M, Smith N, Jovanovic B, Xin D, Liang L, Guo Y, Lee C. The leader sequence triggers and enhances several functions of clusterin and is instrumental in the progression of human prostate cancer in vivo and in vitro. BJU Int. 2006; 98:45260. https://doi.org/10.1111/j.1464-410X.2006.06263.x.

137. Tolcher AW, Reyno L, Venner PM, Ernst SD, Moore M, Geary RS, Chi K, Hall S, Walsh W, Dorr A, Eisenhauer E. A randomized phase II and pharmacokinetic study of the antisense oligonucleotides ISIS 3521 and ISIS 5132 in patients with hormone-refractory prostate cancer. Clin Cancer Res. 2002; 8:2530-35.

138. Tolcher AW, Chi K, Kuhn J, Gleave M, Patnaik A, Takimoto C, Schwartz G, Thompson I, Berg K, D'Aloisio S, Murray N, Frankel SR, Izbicka E, Rowinsky E. A phase II, pharmacokinetic, and biological correlative study of oblimersen sodium and docetaxel in patients with hormonerefractory prostate cancer. Clin Cancer Res. 2005; 11:385461. https://doi.org/10.1158/1078-0432.CCR-04-2145.

139. Di Cresce C, Koropatnick J. Antisense treatment in human prostate cancer and melanoma. Curr Cancer Drug Targets. 2010; 10:555-65. https://doi.org/10.2174/15680091079185 9452.

140. Gutschner T, Hämmerle M, Eissmann M, Hsu J, Kim Y, Hung G, Revenko A, Arun G, Stentrup M, Gross M, Zörnig M, MacLeod AR, Spector DL, Diederichs S. The noncoding RNA MALAT1 is a critical regulator of the metastasis phenotype of lung cancer cells. Cancer Res. 2013; 73:1180-89. https://doi.org/10.1158/0008-5472. CAN-12-2850.

141. Smaldone MC, Davies BJ. BC-819, a plasmid comprising the $\mathrm{H} 19$ gene regulatory sequences and diphtheria toxin A, for the potential targeted therapy of cancers. Curr Opin Mol Ther. 2010; 12:607-16.

142. Mizrahi A, Czerniak A, Levy T, Amiur S, Gallula J, Matouk I, Abu-lail R, Sorin V, Birman T, de Groot N,
Hochberg A, Ohana P. Development of targeted therapy for ovarian cancer mediated by a plasmid expressing diphtheria toxin under the control of H19 regulatory sequences. J Trans1 Med. 2009; 7:69. https://doi.org/10.1186/1479-5876-7-69.

143. Amit D, Hochberg A. Development of targeted therapy for bladder cancer mediated by a double promoter plasmid expressing diphtheria toxin under the control of H19 and IGF2-P4 regulatory sequences. J Transl Med. 2010; 8:134. https://doi.org/10.1186/1479-5876-8-134.

144. Amit D, Matouk IJ, Lavon I, Birman T, Galula J, AbuLail R, Schneider T, Siegal T, Hochberg A, Fellig Y. Transcriptional targeting of glioblastoma by diphtheria toxin-A driven by both $\mathrm{H} 19$ and IGF2-P4 promoters. Int J Clin Exp Med. 2012; 5:124-35.

145. Mizrahi A, Czerniak A, Ohana P, Amiur S, Gallula J, Matouk I, Abu-Lail R, Birman T, Hochberg A, Levy T. Treatment of ovarian cancer ascites by intra-peritoneal injection of diphtheria toxin A chain-H19 vector: a case report. J Med Case Reports. 2010; 4:228. https://doi. org/10.1186/1752-1947-4-228.

146. Sidi AA, Ohana P, Benjamin S, Shalev M, Ransom JH, Lamm D, Hochberg A, Leibovitch I. Phase I/II marker lesion study of intravesical BC-819 DNA plasmid in H19 over expressing superficial bladder cancer refractory to bacillus Calmette-Guerin. J Urol. 2008; 180:2379-83. https://doi.org/10.1016/j.juro.2008.08.006.

147. Rupaimoole R, Lee J, Haemmerle M, Ling H, Previs RA, Pradeep S, Wu SY, Ivan C, Ferracin M, Dennison JB, Millward NM, Nagaraja AS, Gharpure KM, et al. Long noncoding RNA ceruloplasmin promotes cancer growth by altering glycolysis. Cell Reports. 2015; 13:2395-402. https://doi.org/10.1016/j.celrep.2015.11.047.

148. Wang F, Ren S, Chen R, Lu J, Shi X, Zhu Y, Zhang W, Jing T, Zhang C, Shen J, Xu C, Wang H, Wang H, et al. Development and prospective multicenter evaluation of the long noncoding RNA MALAT-1 as a diagnostic urinary biomarker for prostate cancer. Oncotarget. 2014; 5:11091102. https://doi.org/10.18632/oncotarget.2691.

149. Jiang $\mathrm{H}$, Hu X, Zhang H, Li W. Down-regulation of LncRNA TUG1 enhances radiosensitivity in bladder cancer via suppressing HMGB1 expression. Radiat Oncol. 2017; 12:65. https://doi.org/10.1186/s13014-017-0802-3.

150. Zhou Y, Wang C, Liu X, Wu C, Yin H. Long non-coding RNA HOTAIR enhances radioresistance in MDA-MB231 breast cancer cells. Oncol Lett. 2017; 13:1143-48. https:// doi.org/10.3892/ol.2017.5587.

151. Lu H, He Y, Lin L, Qi Z, Ma L, Li L, Su Y. Long non-coding RNA MALAT1 modulates radiosensitivity of HR-HPV+ cervical cancer via sponging miR-145. Tumour Biol. 2016; 37:1683-91. https://doi.org/10.1007/s13277-015-3946-5. 